\title{
Iron and sulfate reduction structure microbial communities in (sub-) Antarctic sediments
}

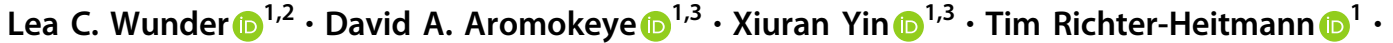 \\ Graciana Willis-Poratti $^{1,4,5} \cdot$ Annika Schnakenberg ${ }^{1,2} \cdot$ Carolin Otersen $^{1} \cdot$ Ingrid Dohrmann $^{6} \cdot$ Miriam Römer $^{3,7}$. \\ Gerhard Bohrmann $^{3,7} \cdot$ Sabine Kasten ${ }^{3,6,7} \cdot$ Michael W. Friedrich $\mathbb{D}^{1,3}$
}

Received: 11 November 2020 / Revised: 4 May 2021 / Accepted: 12 May 2021 / Published online: 21 June 2021

(c) The Author(s) 2021. This article is published with open access

\begin{abstract}
Permanently cold marine sediments are heavily influenced by increased input of iron as a result of accelerated glacial melt, weathering, and erosion. The impact of such environmental changes on microbial communities in coastal sediments is poorly understood. We investigated geochemical parameters that shape microbial community compositions in anoxic surface sediments of four geochemically differing sites (Annenkov Trough, Church Trough, Cumberland Bay, Drygalski Trough) around South Georgia, Southern Ocean. Sulfate reduction prevails in Church Trough and iron reduction at the other sites, correlating with differing local microbial communities. Within the order Desulfuromonadales, the family Sva1033, not previously recognized for being capable of dissimilatory iron reduction, was detected at rather high relative abundances (up to $5 \%$ ) while other members of Desulfuromonadales were less abundant $(<0.6 \%)$. We propose that Sva1033 is capable of performing dissimilatory iron reduction in sediment incubations based on RNA stable isotope probing. Sulfate reducers, who maintain a high relative abundance of up to $30 \%$ of bacterial $16 \mathrm{~S}$ rRNA genes at the iron reduction sites, were also active during iron reduction in the incubations. Thus, concurrent sulfate reduction is possibly masked by cryptic sulfur cycling, i.e., reoxidation or precipitation of produced sulfide at a small or undetectable pool size. Our results show the importance of iron and sulfate reduction, indicated by ferrous iron and sulfide, as processes that shape microbial communities and provide evidence for one of Sva1033's metabolic capabilities in permanently cold marine sediments.
\end{abstract}

\section{Introduction}

Organic matter degradation is the main source of electron donors and carbon for microbial metabolism in marine

These authors contributed equally: Lea C. Wunder, David A. Aromokeye

Supplementary information The online version contains supplementary material available at https://doi.org/10.1038/s41396021-01014-9.

David A. Aromokeye

david.aromokeye@uni-bremen.de

Michael W. Friedrich

michael.friedrich@uni-bremen.de

1 Microbial Ecophysiology Group, Faculty of Biology/Chemistry, University of Bremen, Bremen, Germany

2 Max Planck Institute for Marine Microbiology, Bremen, Germany sediments $[1,2]$. The estimated $5.39 \times 10^{29}$ microbial cells in marine sediments [3] form a microbial food chain. Below the oxic zone, the anaerobic portion of this food chain starts with specialists, which perform hydrolytic and fermentative processes [4], and ends with anaerobically respiring microorganisms, which oxidize fermentation products with available terminal electron acceptors such as nitrate, $\mathrm{Mn}(\mathrm{IV}), \mathrm{Fe}(\mathrm{III})$, sulfate, and $\mathrm{CO}_{2}$. Because nitrate and $\mathrm{Mn}(\mathrm{IV})$ are rapidly depleted in the uppermost centimeters of most coastal and upper slope surface sediments [2, 5], sulfate and $\mathrm{Fe}(\mathrm{III})$ are the most abundant terminal electron

3 MARUM - Center for Marine Environmental Sciences, University of Bremen, Bremen, Germany

4 Instituto Antártico Argentino, Buenos Aires, Argentina

5 Facultad de Ciencias Exactas, Universidad Nacional de La Plata, Buenos Aires, Argentina

6 Alfred Wegener Institute Helmholtz Centre for Polar and Marine Research, Bremerhaven, Germany

7 Faculty of Geosciences, University of Bremen, Bremen, Germany 
acceptors utilized by microorganisms for mineralization of fermentation products in these depositional environments [6-8].

Iron enters the ocean from various sources including terrigenous origins via weathering and erosion and subsequent transport by rivers and windblown dust; hydrothermal vents [9]; melting sea ice and icebergs [10]; and glacial associated erosion, weathering, and meltwater [11-14]. Due to global warming, glacial associated input of iron is predicted to increase in the future, resulting in enhanced amounts of iron reaching coastal sediments and adjacent ocean areas especially in higher latitudes $[13,15,16]$. Sulfate, which is generally present in high concentrations in the water column ( $28 \mathrm{mM})$, is supplied to the sediment by downward diffusion, accelerated by bio-irrigation and other advective processes [7, 8, 17]. In addition, it is the final product of reoxidation of sulfide [18, 19], which itself is produced by sulfate reduction [20], potentially resulting in a cryptic sulfur cycle $[18,19,21]$. Iron reduction is constrained by the reactivity and lower availability of ferric iron compared to sulfate $[5,22]$. Therefore, while iron reduction is favored in certain marine settings [23, 24], organic matter oxidation by sulfate reduction is often more important than iron reduction in marine sediments [7, 8], a competition shown to be also regulated by the availability and reactivity of organic matter and ferric iron [22, 25].

Geochemical and biogeochemical factors have been previously shown to be key parameters shaping the microbial communities in marine sediments [1, 26, 27]. Besides the availability of terminal electron acceptors [1], i.e., $\mathrm{Fe}(\mathrm{III})$ and sulfate, these factors include quantity, composition, and reactivity of organic matter [26, 28, 29], sediment geochemistry [27, 30, 31], salinity [32], temperature [33], ocean currents [34], primary productivity in the overlying water column [35], and sedimentation rate [24].

The permanently cold surface sediments around the island of South Georgia in the South Atlantic Ocean, which we have investigated in this study, are influenced by high organic matter content around the shelf areas $(0.65 \mathrm{wt} \%$ Cumberland Bay [36]), and high iron content within or close to the fjords (ref. [37], Cumberland Bay: total Fe solid phase $47 \mathrm{~g} / \mathrm{kg}$ [38]; $0.7 \mathrm{wt} \%$ ferrihydrite and lepidocrocite [39]). In addition, the studied sediments were found to be characterized by widespread active methane seepage within the fjords and on the shelf, mostly associated with crossshelf glacial troughs [36, 40, 41]. So far, we studied the microbial communities inhabiting deeper sediments (down to $10 \mathrm{~m}$ below seafloor) at three sites around South Georgia [42] and in the present study, a detailed analysis of the surface sediments at very fine scales is provided.

The sediments of the second study site Potter Cove, a small fjord located at the southwest of King George Island/ Isla 25 de Mayo (South Shetland Islands) on the northern tip of the West Antarctic Peninsula, are characterized by a high input of iron from glacial meltwater and bedrock erosion $[13,14,43]$. Especially, sediments close to the glacier termination show a deeper ferruginous zone compared with sediments not directly influenced by glaciers [14] similarly to Cumberland Bay, South Georgia [41].

We hypothesize that differing geochemical characteristics in the surface sediments (top $20-30 \mathrm{~cm}$ ) at various sites around South Georgia shape the local microbial communities. To test this hypothesis, four sites, located on the outer shelf (Annenkov Trough, Church Trough) or within or close to one of the fjords (Cumberland Bay, Drygalski Trough), were selected around the island of South Georgia. These sites were characterized by either high ferrous iron or hydrogen sulfide concentrations. The microbial communities of these sediments were investigated by $16 \mathrm{~S}$ rRNA gene sequencing, quantitative PCR and RNA stable isotope probing (SIP) incubations. Correlation and multivariate regression analyses were performed to identify which geochemical parameters primarily shape the microbial community composition. The active iron-reducing microbial community of South Georgia sediments was compared to those in geochemically similar sediments of Potter Cove (Antarctic Peninsula) using RNA-SIP experiments.

\section{Materials and methods}

\section{Study area and sampling}

Samples from South Georgia sediments were collected during the RV METEOR M134 expedition in January to February 2017 [41]. To study microbial communities in the surface sediments (Fig. 1), four sites were selected: two sites on the outer shelf (Church Trough, Annenkov Trough) and two sites within or close to one of the fjords (Cumberland Bay and Drygalski Trough, respectively). All sites are located close to $(<500 \mathrm{~m})$ areas where active methane seepage has been observed from the sediments during the M134 cruise [41]. Surface sediments were retrieved using a multicorer (MUC, length $50 \mathrm{~cm}$ ). The exact coordinates and sampling information are provided in Table S1.

For each station, two replicate MUC cores were retrieved, one for pore water geochemistry and one for microbiology. Sampling for both geochemistry and microbiology was done on board of the ship in a cold room at $4{ }^{\circ} \mathrm{C}$. Microbiology samples were frozen in liquid nitrogen and transported to Bremen for molecular biology analyses. In addition, a gravity core (10 m length) was retrieved from the site in Cumberland Bay (detailed information Table S1) and kept at $4{ }^{\circ} \mathrm{C}$ until and during transport back to Bremen where it was sectioned and stored anoxically until use. 
Fig. 1 Sampling locations around South Georgia. Core identifications are displayed, the red marked core was used for SIP incubations.

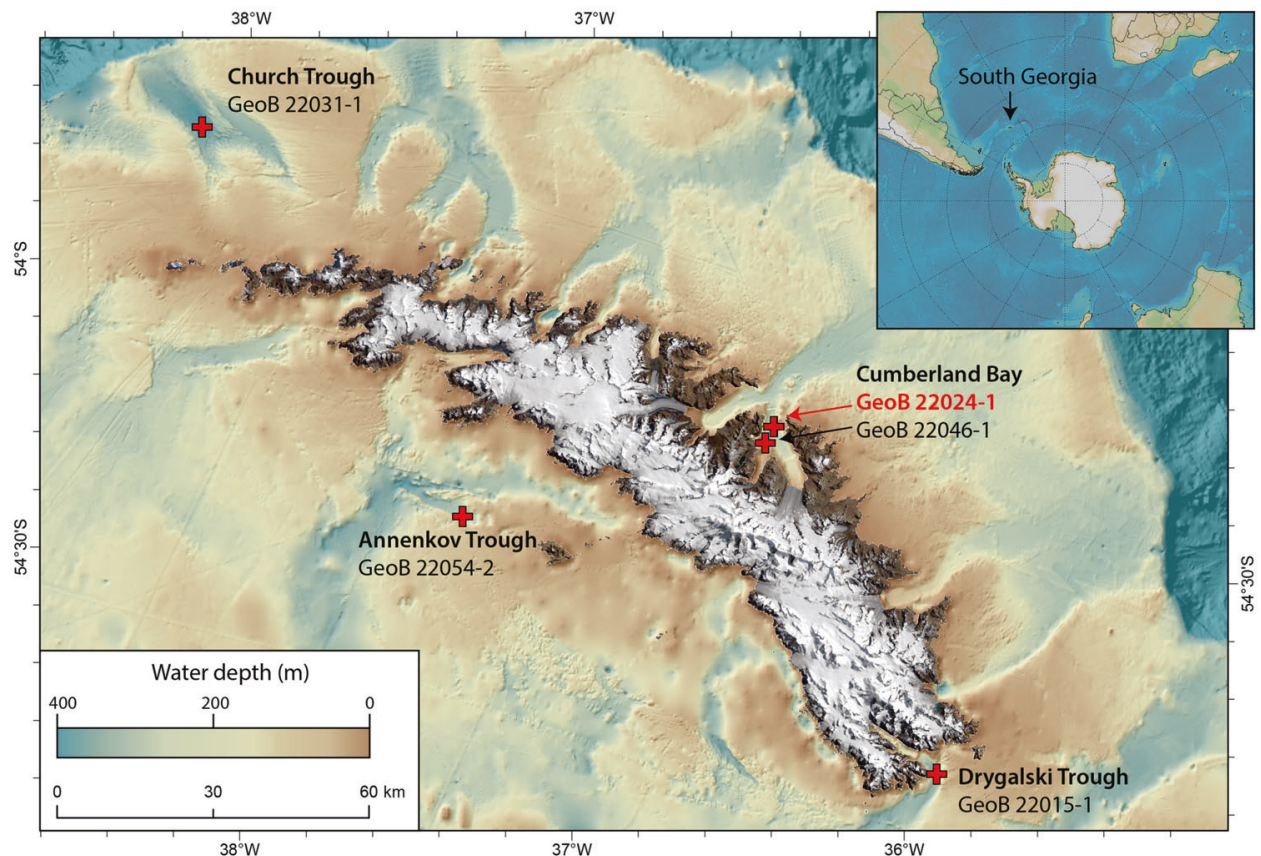

Antarctic surface sediments from Potter Cove (King George Island/Isla 25 de Mayo), Station 13, were retrieved during a field campaign with a push core in January 2019 (detailed information Table S1). The sampling site (Fig. S1) and geochemistry were previously described in Henkel et al. [14].

\section{Pore water geochemistry}

Pore water was retrieved from the MUC and gravity cores using rhizon samplers according to the procedure described by Seeberg-Elverfeldt et al. [44]. Dissolved iron(II) $\left(\mathrm{Fe}^{2+}\right)$, phosphate $\left(\mathrm{PO}_{4}{ }^{3-}\right)$, ammonium $\left(\mathrm{NH}_{4}{ }^{+}\right)$, dissolved inorganic carbon (DIC) and silicate $\left(\mathrm{SiO}_{2}\right)$ were measured on-board as described in Bohrmann et al. [41], while samples for sulfate $\left(\mathrm{SO}_{4}{ }^{2-}\right.$, diluted 1:50 with Milli-Q water) and hydrogen sulfide $\left(\mathrm{H}_{2} \mathrm{~S}\right.$, fixation in $2.5 \%$ zinc-acetate solution) measurements were stored for later analysis. $\mathrm{H}_{2} \mathrm{~S}$ and $\mathrm{SO}_{4}{ }^{2-}$ measurements were performed following Oni et al. [45].

\section{DNA extraction and 16S rRNA gene sequencing}

To explore the microbial communities in the South Georgia surface sediments, $1.5 \mathrm{~g}$ of frozen sediment was taken from 10 depths per site, selected according to the geochemical profiles, for DNA extraction. DNA extraction (by a phenolchloroform protocol), PCR, and amplicon sequencing on a HiSeq 4000 System (Illumina, San Diego, CA; 2x 150 bp, only forward reads analyzed) at GATC GmbH (Konstanz, Germany) of bacterial and archaeal 16S rRNA genes were done following Aromokeye et al. [46]. The primer pair Bac515F (5'-GTGYCAGCMGCCGCGGTAA-3'; ref. [47]) and Bac805R (5'-GACTACHVGGGTATCTAATCC-3'; ref. [48]) targeted bacteria and the primer pair Arc519F (5'-CAGCMGCCGCGGTAA-3'; ref. [49]) and Arc806R (5'-GGACTACVSGGGTATCTAAT-3'; ref. [50]) targeted archaea. Unassigned reads or those assigned to chloroplasts, mitochondria, and archaea (in the bacterial dataset) or bacteria (in the archaeal dataset) were removed from the OTU tables. Normalization of sequencing data was done by calculating relative abundances, which were summed up for each taxon on all available ranks (for more details see supplementary methods, Table S2 and Fig. S2).

\section{SIP experiments using (sub-)Antarctic sediments}

RNA-SIP incubations were set up in order to identify active iron reducers using the top sediments of a gravity core from Cumberland Bay, South Georgia (GeoB22024-1; 0-14 cm, stored at $4{ }^{\circ} \mathrm{C}$ ). The setup is described in more detail in the supplementary methods. Briefly, $40 \mathrm{ml}$ anoxic slurries were prepared at a ratio of 1:4 of sediment and sulfate-free artificial seawater (per liter $26.4 \mathrm{~g} \mathrm{NaCl}, 11.2 \mathrm{~g} \mathrm{MgCl}_{2} \cdot 6 \mathrm{H}_{2} \mathrm{O}$, $1.5 \mathrm{~g} \mathrm{CaCl}_{2} \cdot 2 \mathrm{H}_{2} \mathrm{O}, 0.7 \mathrm{~g} \mathrm{KCl}$, prepared with purified water (Milli-Q)). Before addition of substrates, slurries were preincubated at $5{ }^{\circ} \mathrm{C}$ in the dark for $4-6$ days to allow for system equilibration and pre-reduce small amounts of alternative electron acceptors (e.g., nitrate) potentially present in the starting sediments. Four different treatments were set up in triplicates (Table S3), containing $0.5 \mathrm{mM}$ ${ }^{13} \mathrm{C}$-labeled acetate as electron donor and carbon source and as electron acceptor either $5 \mathrm{mM}$ lepidocrocite, $5 \mathrm{mM}$ sulfate, or none. Lepidocrocite was chosen as easily reducible 
iron oxide typically found in surface sediments, including the study site [39]. One treatment contained $10 \mathrm{mM}$ sodium molybdate in addition to lepidocrocite in order to inhibit sulfate reduction. For each treatment, a control with unlabeled $\left({ }^{12} \mathrm{C}\right)$ acetate was set up. An unamended incubation with only sediment and artificial sea water was used as control. Aqueous $\mathrm{Fe}^{2+}$ formation was monitored during the course of the incubation for each bottle individually using a ferrozine assay [51], modified by fixing the samples in $0.5 \mathrm{M} \mathrm{HCl}$ in order to prevent further oxidation. Aqueous sulfate was measured at day 0 and day 15 (end point) of the incubation using a Metrohm 930 Compact IC Flex ion chromatograph. After 15 days, RNA was extracted from pooled triplicates in order to retrieve sufficient biomass for fractionation.

To support the observations from Cumberland Bay, a second SIP experiment was performed using Antarctic sediments from Potter Cove (push core 0-29 cm) with similar geochemistry as Cumberland Bay [14, 36]. For Potter Cove sediment incubations, the procedure for experimental setup and $\mathrm{Fe}^{2+}$ measurement was similar as described above with the modifications of using only $30 \mathrm{ml}$ slurry (ratio 1:6) in 60- $\mathrm{ml}$ serum bottles, an incubation temperature of $2{ }^{\circ} \mathrm{C}$ and a pre-incubation time of 7 days. The single treatment contained $0.5 \mathrm{mM}{ }^{13} \mathrm{C}$-labeled or unlabeled acetate and $5 \mathrm{mM}$ lepidocrocite as substrate. The incubation was carried out for 10 days.

\section{RNA-SIP}

The steps of nucleic acid extraction, removal of DNA, quantification, density separation, and preparation of $16 \mathrm{~S}$ rRNA sequencing were performed following a previously described protocol [52] with the following modifications. Briefly, nucleic acids were extracted from $15 \mathrm{ml}$ slurry per treatment, using a phenol-chloroform extraction protocol, followed by DNase treatment and an additional phenolchloroform purification and RNA precipitation step with isopropanol and sodium acetate. RNA was quantified with Quanti-iT RiboGreen and $1 \mu \mathrm{g}$ was used for density separation by ultracentrifugation. This resulted in 14 fractions of which fraction 1 had the highest density (= heaviest) and fraction 14 the lowest. The RNA content of each fraction was quantified and fractions were defined and pooled by their RNA concentration-density profile as ultra-heavy $=$ fraction $3+4$ $(1.814-1.826 \mathrm{~g} / \mathrm{ml}) ;$ heavy $=$ fraction $5+6(1.799-1.810 \mathrm{~g} /$ $\mathrm{ml})$; midpoint $=$ fraction $7+8(1.783-1.799 \mathrm{~g} / \mathrm{ml}) ;$ light $=$ fraction $9+10(1.768-1.783 \mathrm{~g} / \mathrm{ml})$; ultra-light $=$ fraction $11+$ $12(1.753-1.768 \mathrm{~g} / \mathrm{ml})$. The pooled fractions were used for cDNA synthesis. The bacterial 16S rRNA amplicon library was prepared as previously described [46] and paired-end sequenced at Novogene Co. Ltd. (Cambridge, UK) using Novaseq6000 platform (2x $250 \mathrm{bp}$ ). Sequencing analysis was done following Aromokeye et al. [46] with modifications described in the supplementary material (sequencing details Table S4 and Fig. S3) and in the 16S rRNA gene sequencing paragraph above.

\section{Quantitative PCR}

Bacterial and archaeal 16S rRNA gene copy numbers of South Georgia surface sediments were determined by quantitative real-time PCR (qPCR). The qPCR assay followed Aromokeye et al. [53] with 1 ng DNA template and a cycling program of $95^{\circ} \mathrm{C}: 5 \mathrm{~min} ; 40$ cycles at $95^{\circ} \mathrm{C}: 15$ or $30 \mathrm{~s}, 58^{\circ} \mathrm{C}$ : $30 \mathrm{~s}, 72^{\circ} \mathrm{C}$ : $40 \mathrm{~s}$ (Table S5); with efficiencies $>80 \%$ and $R^{2}>0.99$. For bacteria quantification, the primers Bac8Fmod (5'-AGAGTTTGATYMTGGCTCAG-3'; modified from ref. [54]) and Bac338Rmod (5'-GCWGCCWCCCGTAGGWGT3'; modified from ref. [55]) were used. For archaea quantification Ar806F (5'-ATTAGATACCCSBGTAGTCC-3'; alternative name Arc787F in ref. [55]) and Ar912rt (5'GTGCTCCCCCGCCAATTCCTTTA-3'; ref. [56]) were used. The gene copy number calculation was based on standard curves of 16S rRNA gene fragments of Escherichia coli (strain SB1) and Methanosarcina barkeri (strain DSM800), amplified with 27F (5'-AGAGTTTGATCCTGGCTCAG-3'; ref. [57]) and Ba1492 (5'-GGTTACCTTGTTACGACTT-3'; ref. [57]), and 109F (5'-ACKGCTCAGTAACACGT-3'; ref. [58]) and A1492 (5'-GGCTACCTTGTTACGACTT-3'; ref. [57]) primer pairs, respectively (Table S5), prepared and analyzed according to Reyes et al. [59].

In surface sediment samples and Cumberland Bay SIP fractions, the functional gene for sulfate reduction, alphasubunit of the dissimilatory sulfite reductase $(d s r A)$, was used for the quantification of sulfate reducers following the qPCR protocol of Reyes et al. [59]. For the qPCR reaction, the primer pair DSR1-F+ (5'-ACSCACTGGAAGCAC GGCGG-3'; ref. [60]) and DSR-R (5'-GTGGMRCCG TGCAKRTTGG-3'; ref. [60]) was used. As standard, the $d s r A B$ gene of Desulfovibrio burkinensis (strain DSM 6830) was amplified with a mix of modified DSR1F/DSR4R primers (for details see Reyes et al. [59]).

\section{Statistical analysis}

Selected pairwise Pearson correlations were calculated between OTU abundances, gene copy numbers, and environmental variables. A distance-based redundancy analysis (dbRDA) was performed on a Bray-Curtis dissimilarity distance matrix between geochemical parameters and bacterial relative abundances from sequencing and tested for predictor variable collinearity, statistical significance (at $p<0.05$ ) for the full model, and constrains for each variable. $P$ values were adjusted for multiple testing according to the false discovery method [61], if necessary. 
All statistical analysis and figures were made within the $\mathrm{R}$ environment version 3.6.1 [62] using the vegan package [63].

Closest sequences of the most abundant OTUs assigned as Sva1033 were exported from 16S rRNA gene ARB tree of Silva release 138 (SILVA_138_SSURef_NR99_ 05_01_20, ref. [64]; >1300 bp, randomly selected) as well as closest named neighboring clusters. A maximum-likelihood tree was inferred with RAxML (version 8.2.11, ref. [65]) using the GTRGAMMA model with 1000 times rapid bootstrapping. The tree file was visualized using iTOL software (v4, ref. [66]) and edited in Inkscape (version 1.0.1, ref. [67]).

\section{Results}

\section{Pore water geochemistry}

Seven different geochemical pore water parameters were analyzed in the context of their correlation to the microbial community in the sediment. Notable differences across the sites were observed in the pore water concentrations and profiles of $\mathrm{Fe}^{2+}, \mathrm{SO}_{4}{ }^{2-}$, and $\mathrm{H}_{2} \mathrm{~S}$ (Fig. 2). Of all parameters, $\mathrm{Fe}^{2+}$ concentrations showed the strongest variability among the study sites.

At the sampling site in Church Trough, $\mathrm{Fe}^{2+}$ became rapidly depleted with depth and undetectable below $3 \mathrm{~cm}$ core depth. Below this depth, downward increasing $\mathrm{H}_{2} \mathrm{~S}$ concentrations (up to $20 \mathrm{mM}$ at $30 \mathrm{~cm}$ ) coincided with decreasing $\mathrm{SO}_{4}{ }^{2-}$ concentrations $(28 \mathrm{mM}$ at $0 \mathrm{~cm}$ to $5 \mathrm{mM}$ at $30 \mathrm{~cm}$ ). This defines the sampling site in Church Trough as being sulfide-rich (Fig. 2). At the other sampling sites, $\mathrm{Fe}^{2+}$ predominated in the sampled sediment interval. The maximum $\mathrm{Fe}^{2+}$ concentration was measured in the sediments sampled in Annenkov Trough $(440 \mu \mathrm{M})$. Therein, $\mathrm{Fe}^{2+}$ concentrations became completely depleted down-core followed by detection of low $\mathrm{H}_{2} \mathrm{~S}$ concentrations below $30 \mathrm{~cm}(500 \mu \mathrm{M})$. In the investigated sediments of both Cumberland Bay and Drygalski Trough, $\mathrm{Fe}^{2+}$ was detected throughout the sampled sediment depth with maximum concentrations of 204 and $256 \mu \mathrm{M}$, respectively, while $\mathrm{H}_{2} \mathrm{~S}$ was below detection limit. The predominance of $\mathrm{Fe}^{2+}$ over $\mathrm{H}_{2} \mathrm{~S}$ in the sediments of these sites thus defines them as iron-rich sites (Fig. 2). In the sediments at the iron-rich sites, $\mathrm{SO}_{4}{ }^{2-}$ concentrations stayed stable with depth $(\sim 28 \mathrm{mM})$ with only minor decreases observed in the surface sediments collected in Cumberland Bay (below $18 \mathrm{~cm}$ from 27 to $23 \mathrm{mM}$ ).

Profiles of $\mathrm{NH}_{4}{ }^{+}$and DIC showed similar distribution and shapes with increasing values over depth at all sites (Fig. 2). DIC concentrations in Church Trough sediments reached double the concentrations observed in the sediments of the other sites toward the bottom of the core. Close
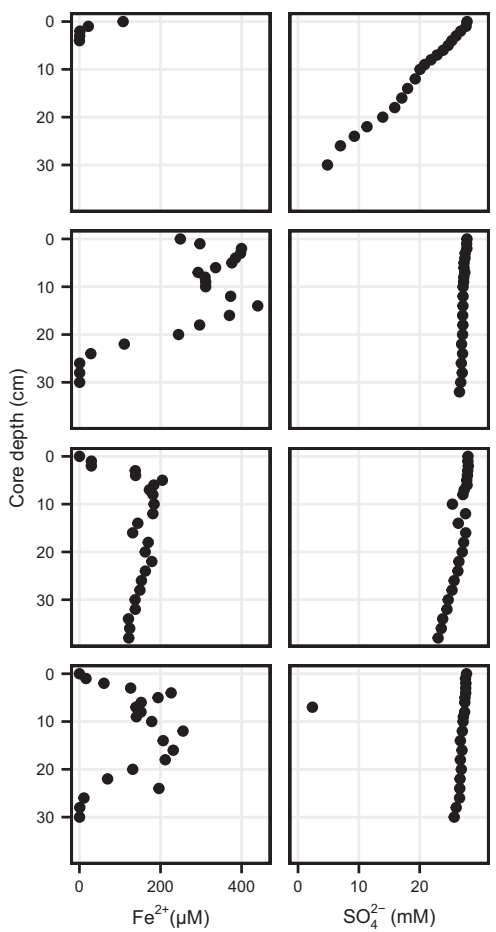
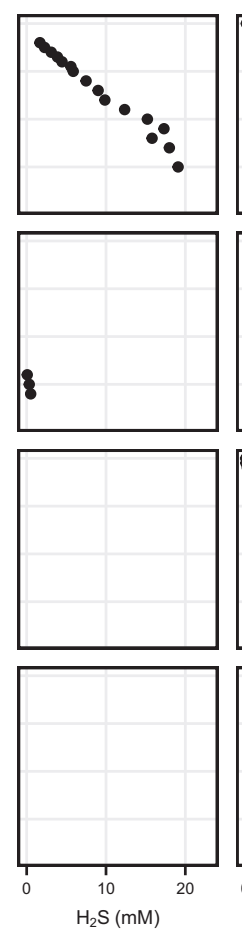
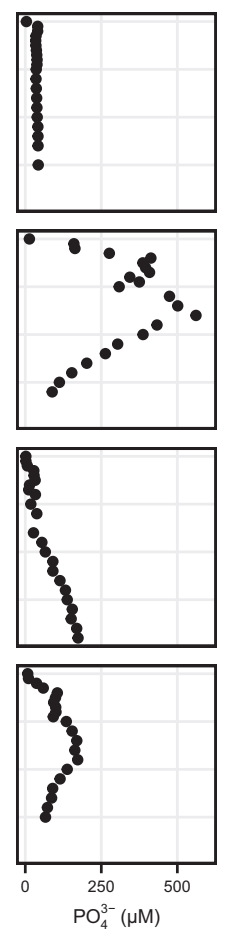
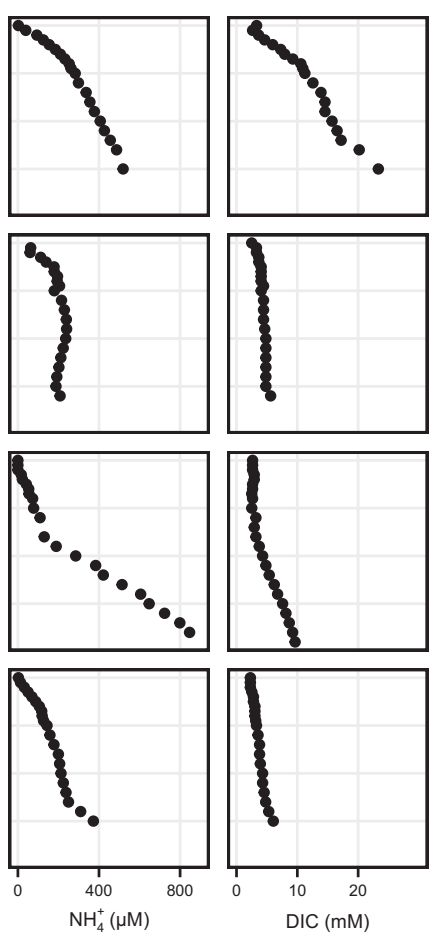
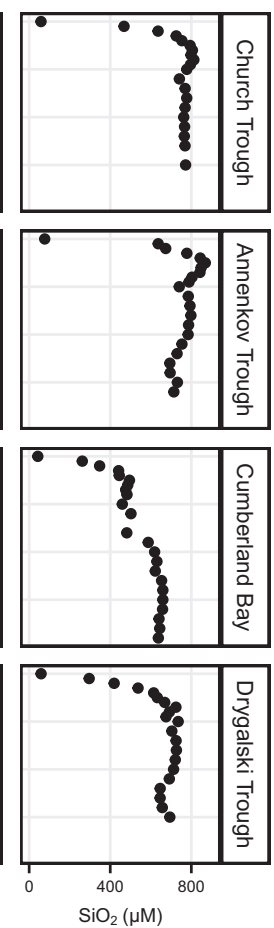

Fig. 2 Pore water concentrations of iron(II) $\left(\mathrm{Fe}^{2+}\right)$, sulfate $\left(\mathrm{SO}_{4}{ }^{2-}\right)$, sulfide $\left(\mathrm{H}_{2} \mathrm{~S}\right)$, phosphate $\left(\mathrm{PO}_{4}{ }^{3-}\right)$, ammonium $\left(\mathrm{NH}_{4}{ }^{+}\right)$, dissolved inorganic carbon (DIC), and silicate $\left(\mathrm{SiO}_{2}\right)$ in surface sediments,
South Georgia. All missing values in $\mathrm{Fe}^{2+}$ and $\mathrm{H}_{2} \mathrm{~S}$ profiles were for data points below detection limit. 
to the surface, $\mathrm{SiO}_{2}$ concentrations increased downward rapidly to a maximum value differing between sites and stayed stable through the rest of the core.

\section{Microbial community composition and abundance estimation}

The bacterial community composition of South Georgia surface sediments was investigated by $16 \mathrm{~S}$ rRNA gene sequencing. Distinct similarities were observed in the distribution of core communities across all sites (Fig. 3A). Relative abundance of sequences falling into Flavobacteriales, the Alphaproteobacteria Rhodobacterales (mostly Rhodobacteraceae); the Gammaproteobacteria Cellvibrionales (mostly Halieaceae); Planctomycetacia (mostly Pirellulaceae); and Verrucomicrobiales (mostly Rubritaleaceae) decreased with sediment depth, while the relative abundance of sequences associated with Anaerolineae

A
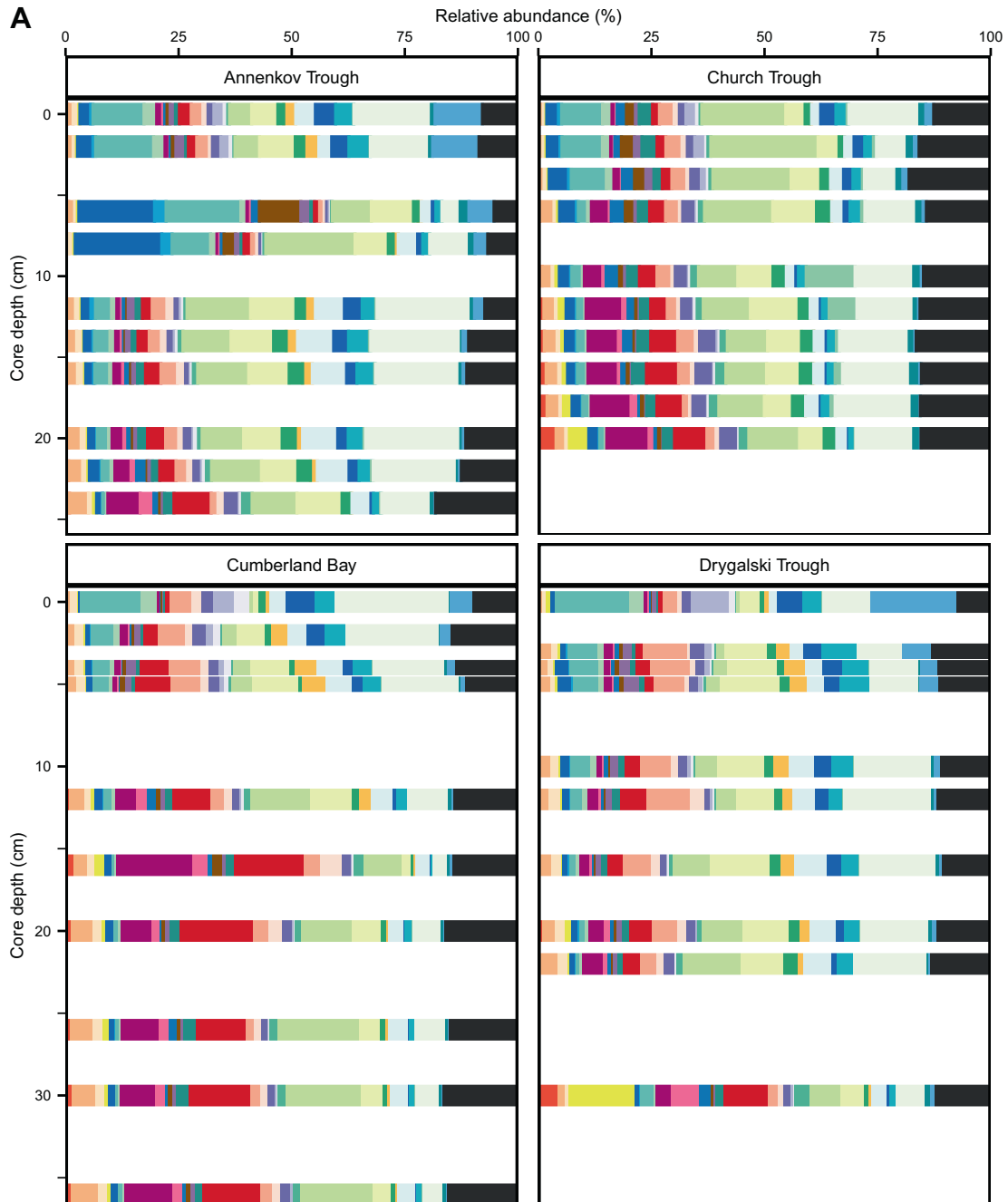
${ }^{100} \mathbf{B}$ B \begin{tabular}{cccc} 
& \multicolumn{3}{c}{ Gene copies / g sediment } \\
$3 \mathrm{e}+00$ & $6 \mathrm{e}+09$ & $9 \mathrm{e}+09$
\end{tabular}

\begin{tabular}{|c|c|}
\hline Phylum Acidobacteria & Phylum Chloroflexi \\
\hline Aminicenantales (Aminicenantia) & Anaerolineae \\
\hline Thermoanaerobaculales (Thermoanaerobaculia) & Dehalococcoidia \\
\hline other Acidobacteria & Phylum Epsilonbacteraeota \\
\hline Phylum Atribacteria & Campylobacterales (Campylobacteria) \\
\hline JS1 & Phylum Firmicutes \\
\hline Phylum Bacteroidetes & Clostridia \\
\hline $\begin{array}{c}\text { Class Bacteroidia } \\
\text { Bacteroidales }\end{array}$ & Phylum Kiritimatiellae \\
\hline Bacteroidetes VC2.1 Bac22 & Phylum Latescibacteria \\
\hline Flavobacteriales & Phylum Planctomycetes \\
\hline other Bacteroidia & $\begin{array}{l}\text { Phycisphaerae } \\
\text { Planctomycetacia }\end{array}$ \\
\hline
\end{tabular}

Phylum Proteobacteria

Class Alphaproteobacteria

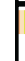

is
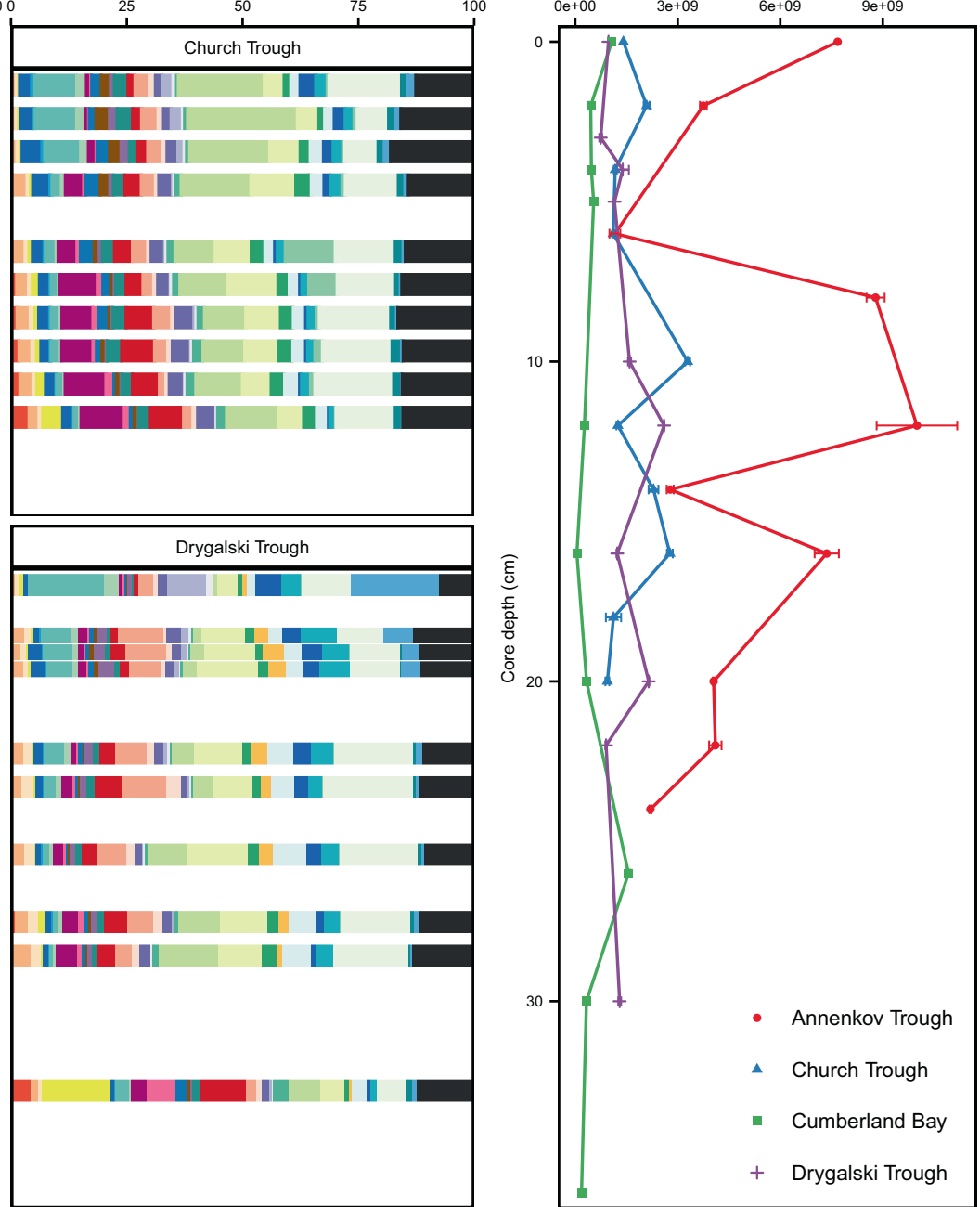

Rhodobacterales

other Alphaproteobacteria

Class Gammaproteobacteria

Cellvibrionales

Gammaproteobacteria Incertae Sedis

Class Deltaproteobacteria

Desulfarculaceae (Desulfarculales)

Desulfobacteraceae (Desulfobacterales)

Desulfobulbaceae (Desulfobacterales)

Methylococcales

other Gammaproteobacteria

Spirochaetia

Myxococcales

Sva1033

other Deltaproteobacteria

Phylum Verrucomicrobia

Verrucomicrobiales

other Bacteria $<2 \%$

other Planctom

Fig. 3 Bacterial community composition and gene copy numbers in South Georgia surface sediments. A Relative abundance of bacterial 16S rRNA genes in 10 depths of Annenkov Trough, Church

Trough, Cumberland Bay and Drygalski Trough. B Bacterial 16S rRNA gene copies per gram wet sediment of samples displayed in (A) with error bars displaying SD of technical qPCR replicates. 
(phylum Chloroflexi), Phycisphaerae (mostly clade MSBL9), and the Atribacteria JS1 increased.

Certain differences between sites were also evident: the relative abundance of Desulfobacteraceae was low $(<5 \%)$ in the top sediments of the iron-rich sites in Annenkov Trough, Cumberland Bay, and Drygalski Trough and only increased down-core, but was very high (18\%) in the top sediments of the sulfide-rich site Church Trough. One major difference between all sites was the presence of Methylococcales throughout the Church Trough core (up to $11 \%$ ), whereas it was present in very low relative abundance at the other sites $(<0.5 \%)$. Conversely, the Desulfuromonadales family Sva1033 was present in all sites but with very low abundance in the Church Trough core (5\% vs. $0.6 \%$ ).

Bacterial 16S rRNA genes were quantified by qPCR with gene copy numbers ranging between $5 \times 10^{7}$ and $1 \times 10^{10}$ copies per gram sediment and differed significantly between sites (Fig. 3B). Specifically, highest gene copy number estimates were obtained from the sediments sampled in Annenkov Trough (up to $1 \times 10^{10}$ at $12 \mathrm{~cm}$ ) and lowest in Cumberland Bay $\left(5 \times 10^{7}-1.6 \times 10^{9}\right)$.

Archaeal sequences recovered after quality filtering were much less compared to bacterial sequences (Table S2). A complete depth profile of the archaeal community was only possible for samples derived from Church Trough and Cumberland Bay (Fig. S4A), because the archaeal read numbers and sequencing depth from the majority of the sampled depths in Drygalski Trough and Annenkov Trough were too low (<900 reads, Table S2). The most abundant archaea in all sites were Bathyarchaeota (up to $31 \%$ in Cumberland Bay) and the genus Candidatus "Nitrosopumilus" (up to $70 \%$ in Cumberland Bay) with their relative abundance decreasing with depth (Fig. S4A). In Church Trough sediments, anaerobic methane oxidizing archaea groups ANME-2a-2b and $-2 c$ were found in high relative abundances below $5 \mathrm{~cm}$ core depth (ANME-2a-2b up to $15 \%$, ANME-2c up to $31 \%$ ). Archaeal $16 \mathrm{~S}$ rRNA gene copy numbers from qPCR were in general a magnitude lower than the bacterial gene copies (Fig. S4B). In contrast to bacterial copy numbers, archaeal copy numbers were highest in Church Trough sediments ranging from $8.6 \times 10^{7}$ to $4.6 \times 10^{8}$ copies per gram sediment. Again, the lowest gene copy numbers of archaea were detected in samples from Cumberland Bay with only $1.6 \times 10^{7}$ to $1.1 \times 10^{8}$ copies.

\section{Statistical correlations between geochemical parameters and bacterial communities}

In order to identify potential geochemical filters that shape the microbial communities across all sites, a dbRDA was performed (Fig. 4, $F=4.99, p<0.01$, Df: 5, 34). $\mathrm{Fe}^{2+}, \mathrm{PO}_{4}{ }^{3-}$, $\mathrm{NH}_{4}{ }^{+}, \mathrm{SiO}_{2}$, and $\mathrm{H}_{2} \mathrm{~S}$ were included as explanatory variables

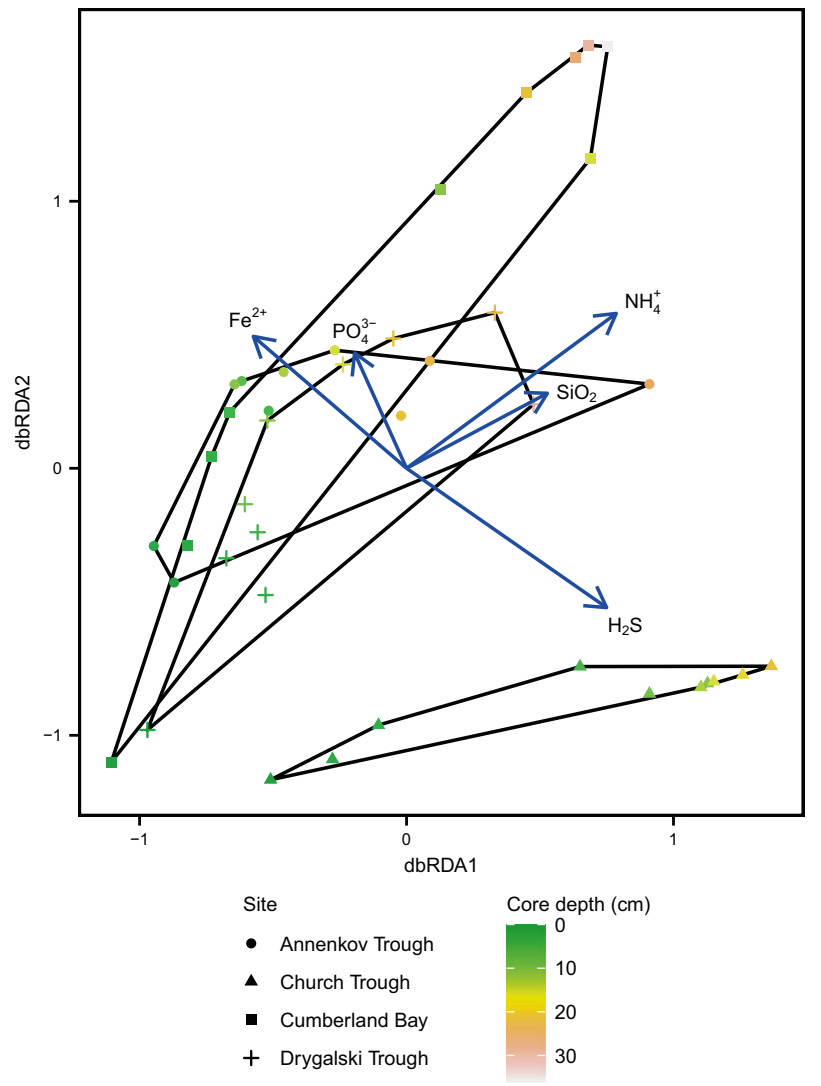

Fig. 4 Distance-based redundancy analysis (dbRDA) ordination plot of bacterial communities in surface sediments of South Georgia. Sample points are distinguished by site and core depth by shape and color, respectively. dbRDA1 (variation 47\%) and dbRDA2 (variation 22\%) axes are displayed, which constrain the Bray-Curtis distance matrix with geochemical parameters $\mathrm{Fe}^{2+}, \mathrm{PO}_{4}{ }^{3-}, \mathrm{NH}_{4}{ }^{+}, \mathrm{SiO}_{2}$, and $\mathrm{H}_{2} \mathrm{~S}$. The total model $(F=4.99, p<0.01$, Df: 5,34$)$ and each individual parameter $(p<0.05)$ was significant.

in the model and together explained $42 \%$ of the total variation in the bacterial community. DIC and $\mathrm{SO}_{4}{ }^{2-}$ were removed due to collinearity to other factors $\left(\mathrm{NH}_{4}{ }^{+}\right.$and $\mathrm{H}_{2} \mathrm{~S}$, respectively). Increasing $\mathrm{NH}_{4}{ }^{+}$concentrations with sediment depth explained most of the variation of the bacterial community $(F=5.85, p<0.01)$, followed by $\mathrm{H}_{2} \mathrm{~S}(F=3.61, p<0.01)$, $\mathrm{SiO}_{2}(F=2.90, p<0.01), \mathrm{Fe}^{2+}(F=2.25, p=0.012)$, and $\mathrm{PO}_{4}{ }^{3-}(F=2.12, p=0.015)$. The clustering in the site ordination space showed a clear distinction between Church Trough and the other three sites (Fig. 4). The model strongly attributed this distinction to $\mathrm{Fe}^{2+}$ and $\mathrm{H}_{2} \mathrm{~S}$ concentration differences between sites. Accordingly, removing these two variables from the model caused the clustering by sampling site in the ordination to disappear (Fig. S5).

Since $\mathrm{H}_{2} \mathrm{~S}$ and $\mathrm{Fe}^{2+}$ concentrations, as indicators for sulfate and iron reduction, were identified as the key environmental factors for the microbial community composition in the sediments (Fig. 4), correlations between these geochemical parameters and taxa known to possess the capability of sulfate and iron reduction were performed. 


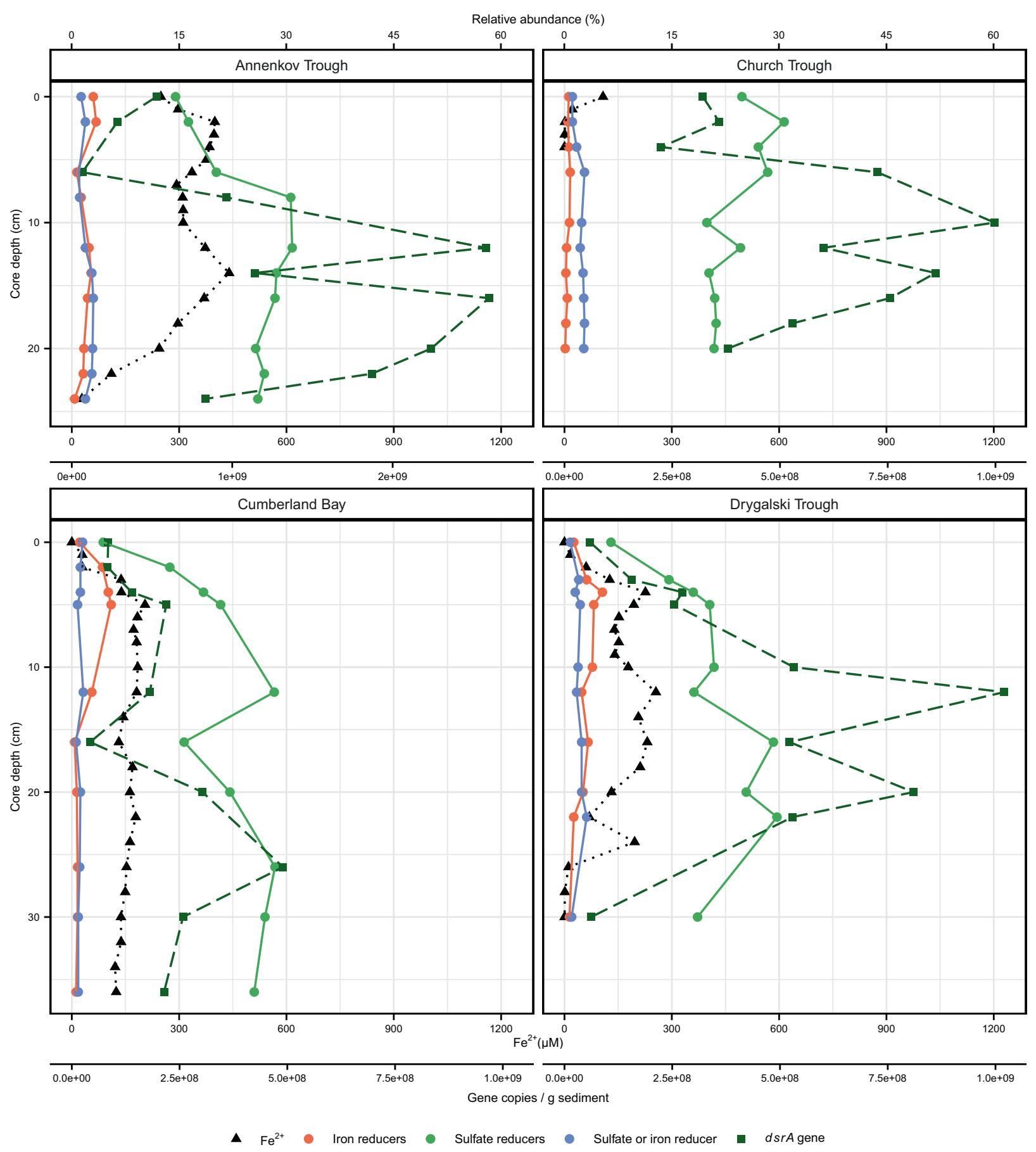

Fig. 5 Depth profile of contribution of sulfate and iron reducing microorganisms in Deltaproteobacteria to bacterial community and quantification of sulfate reducers ( $d s r \mathrm{~A}$ gene) in South Georgia surface sediments. Relative abundance of $16 \mathrm{~S}$ rRNA gene of taxa known for iron and/or sulfate reducing capabilities within Deltaproteobacteria (details in the text) was summed up per sediment depth.

Therefore, relative abundance of known sulfate reducers within the Deltaproteobacteria was summed up for each sample (Fig. 5). This included the taxa Desulfarculales [68], Desulfobacterales [69], Desulfohalobiaceae [70], clade
$\mathrm{Fe}^{2+}$ profile from Fig. 2 and $d s r A$ gene copies per gram wet sediment are displayed. Note the different scale for gene copies/g sediment for Annenkov Trough. Sequences of taxa known for iron reducing capabilities consisted of $>78 \%$ Sva1033 in all depths of Annenkov Trough, Cumberland Bay, and Drygalski Trough.

NB1-j [71], clade SAR324 [72], clade Sva0485 [71], and Syntrophobacterales [73]. Among the known iron reducers from marine sediments (e.g., [74-79]), members of Desulfuromonadales were the most abundant clade in this study. 
Summed up individual families included Desulfuromonadaceae [75, 80], Geobacteraceae [74] and Deferrisoma [81], and the family Sva1033 for which iron reducing capabilities were recently suggested [82]. The taxa Desulfovibrionaceae [83, 84] and Myxococcales [85] were separated as taxa known for both sulfate and iron reduction.

The relative abundance of sulfate reducers was high across all sites (8-30\%; Fig. 5), despite the absence of indication for sulfate reduction, i.e., sulfide accumulation, in the pore water of Cumberland Bay, Drygalski Trough, and Annenkov Trough (Fig. 2). The presence of organisms capable of sulfate reduction was confirmed by qPCR of the $d s r A$ gene as a functional marker gene for sulfate reduction: across all sites, the $d s r A$ gene copies varied between $4.2 \times 10^{7}$ (Cumberland Bay) and $2.6 \times 10^{9}$ copies per gram sediment (Annenkov Trough; Fig. 5) and were positively correlated to the bacterial gene copies $(r=0.74, p<0.001)$. Compared to sulfate reducers, the relative abundance of known iron reducers was lower across the iron-rich sites (1-5\%; Fig. 5). In Church Trough sediments, where sulfate reduction was apparent, relative abundance of iron reducers was lower compared to the other sites $(<0.6 \%)$. A significant correlation between relative abundance of iron reducers and $\mathrm{Fe}^{2+}$ concentrations was found for Drygalski Trough $(r=0.77, p<0.01)$. Correlations were also calculated for the most dominant members of the order Desulfuromonadales, the family Sva1033 (Figs. 3 and S6). Sva1033 showed significant correlations with $\mathrm{Fe}^{2+}$ for Annenkov Trough $(r=0.63, p=0.049)$ and Drygalski Trough $(r=0.77, p<0.01)$, but not Cumberland Bay. Although the highest relative abundance of known (or proposed) bacteria capable of iron reduction was found in Cumberland Bay sediments, depth-wise relative distribution of iron reducers did not correlate with $\mathrm{Fe}^{2+}$ concentrations. Instead, a correlation was found between $\mathrm{Fe}^{2+}$ concentration and relative abundance of known sulfate reducers $(r=0.78, p<0.01)$.

\section{SIP experiments with (sub-)Antarctic sediments}

The abundance and distribution of known iron and sulfate reducers in the sediment communities raised questions about their metabolic activities in this environment. Sva1033 was the dominant member of Desulfuromonadales (Fig. S6), an order known for its iron reducing capabilities (e.g., [74-79]). It was found across all iron-rich sites, but this clade is only so far predicted-but not proven - to perform iron reduction due to phylogenetic affiliation to Desulfuromonadales (ref. [82], Fig. S7). Counterintuitively, sulfate reducers were significantly more abundant compared to iron reducers in the sites where iron reduction prevailed (Fig. 5). To further investigate these observations, we set up RNA-SIP incubations using acetate as ${ }^{13} \mathrm{C}$-labeled substrate with Cumberland Bay surface sediments in order to label active acetate oxidizers with the prediction that ironreducing microorganisms capable of utilizing acetate as electron donor will be labeled in the heavy fractions $[78,86]$. Given that obtaining a pure culture for Sva1033 was outside the scope of this study, we aimed with this strategy to obtain an indirect indication for iron reduction capability in the Sva1033 clade. In these incubations, increasing $\mathrm{Fe}^{2+}$ concentrations were detected in all treatments without significant differences between them, except in the treatment with acetate, lepidocrocite, and molybdate (Fig. S8A). In the molybdate-amended treatment, only moderate increase in $\mathrm{Fe}^{2+}$ concentrations was observed over time. No further increase of $\mathrm{Fe}^{2+}$ concentrations was detected by day 15 of the incubation experiment in all treatments. Sulfate was measured over time (Fig. S8B). A general trend of changing sulfate concentrations could only be observed in the acetate only treatment (decrease by up to $0.4 \mathrm{mM}$ ). Meanwhile, the range of sulfate concentration was different in the treatment amended with $5 \mathrm{mM}$ sulfate (3.8-5.7 mM).

Deltaproteobacteria dominated the general bacterial community in the five defined gradient fractions per treatment (ultra-light, light, midpoint, heavy, ultra-heavy) after isopycnic separation. Their relative abundance ranged from at least $50 \%$ up to over $80 \%$ in some ${ }^{13} \mathrm{C}$ ultra-heavy fractions. Clear differences were observed between the communities in the light and heavy fractions, thus confirming that the SIP separation was successful (Fig. 6A, B). The mostly enriched taxon in the ${ }^{13} \mathrm{C}$ heavy and ultra-heavy fractions of all treatments was Desulfuromonadales within the Deltaproteobacteria (yellow-orange-brown in Fig. 6B), including the family Sva1033 (10-23\%), Desulfuromonas (8-21\%), Geopsychrobacter (8-10\%), and Geothermobacter (8-13\%). In total, the order Desulfuromonadales was more abundant in the ${ }^{13} \mathrm{C}$ incubations, reaching up to $70 \%$ in the ultra-heavy fractions, compared to the ${ }^{12} \mathrm{C}$ control incubations where their relative abundance was below $25 \%$ and mostly in the lighter fractions. Their relative abundance was slightly lower in the ultra-heavy fractions of the sulfate amended treatments (55\%) compared to the other treatments $(64-69 \%)$.

Within the class Deltaproteobacteria, the other abundant taxa were members of Desulfobacterales: Desulfobacteraceae, especially clade Sva0081, and Desulfobulbaceae, which together reached abundances of up to $50 \%$. These groups of known sulfate reducers were more abundant in the ${ }^{13} \mathrm{C}$ acetate and sulfate amended ultra-heavy fraction (23\%) compared to the other ${ }^{13} \mathrm{C}$ acetate amended treatments $(6-18 \%)$. The lowest relative proportion of sulfate reducers in the ultra-heavy fraction $(6 \%)$ was observed in the molybdate amended treatment. Quantification of the $d s r A$ transcripts (Fig. 6C) showed very low copy numbers in the control treatment with molybdate (0-6700 transcript 
A

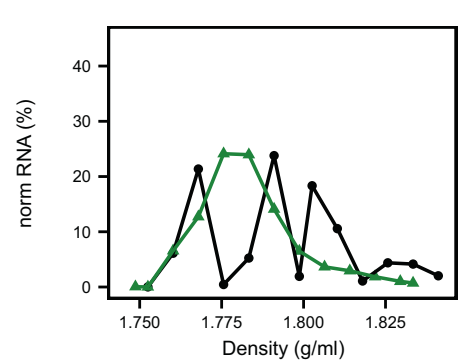

B

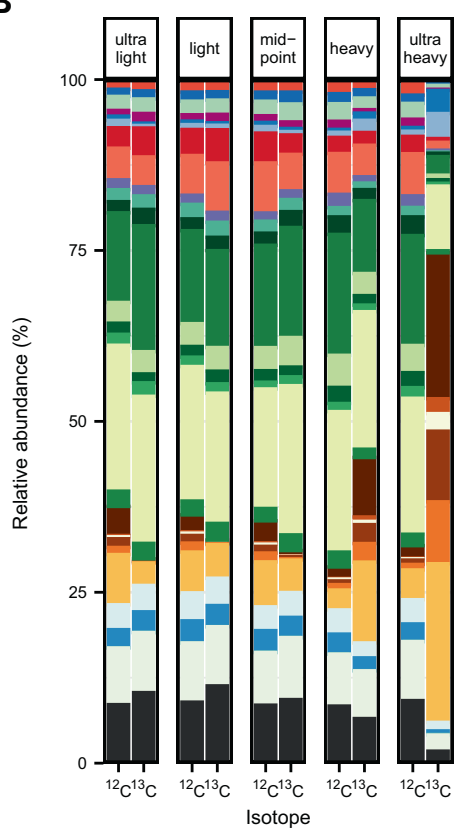

C

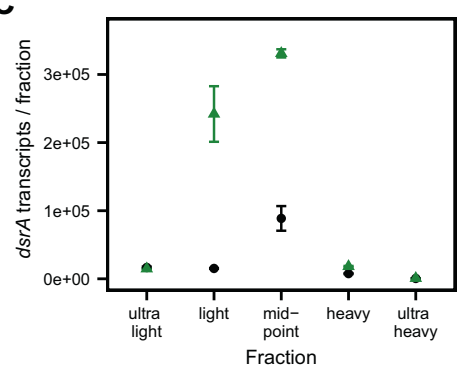

Acetate + lepidocrocite

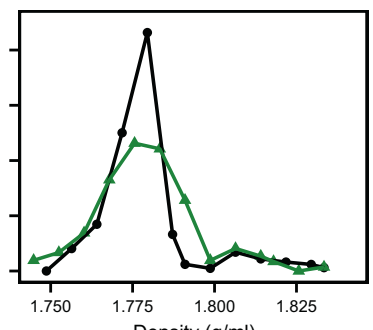

Density $(\mathrm{g} / \mathrm{ml})$
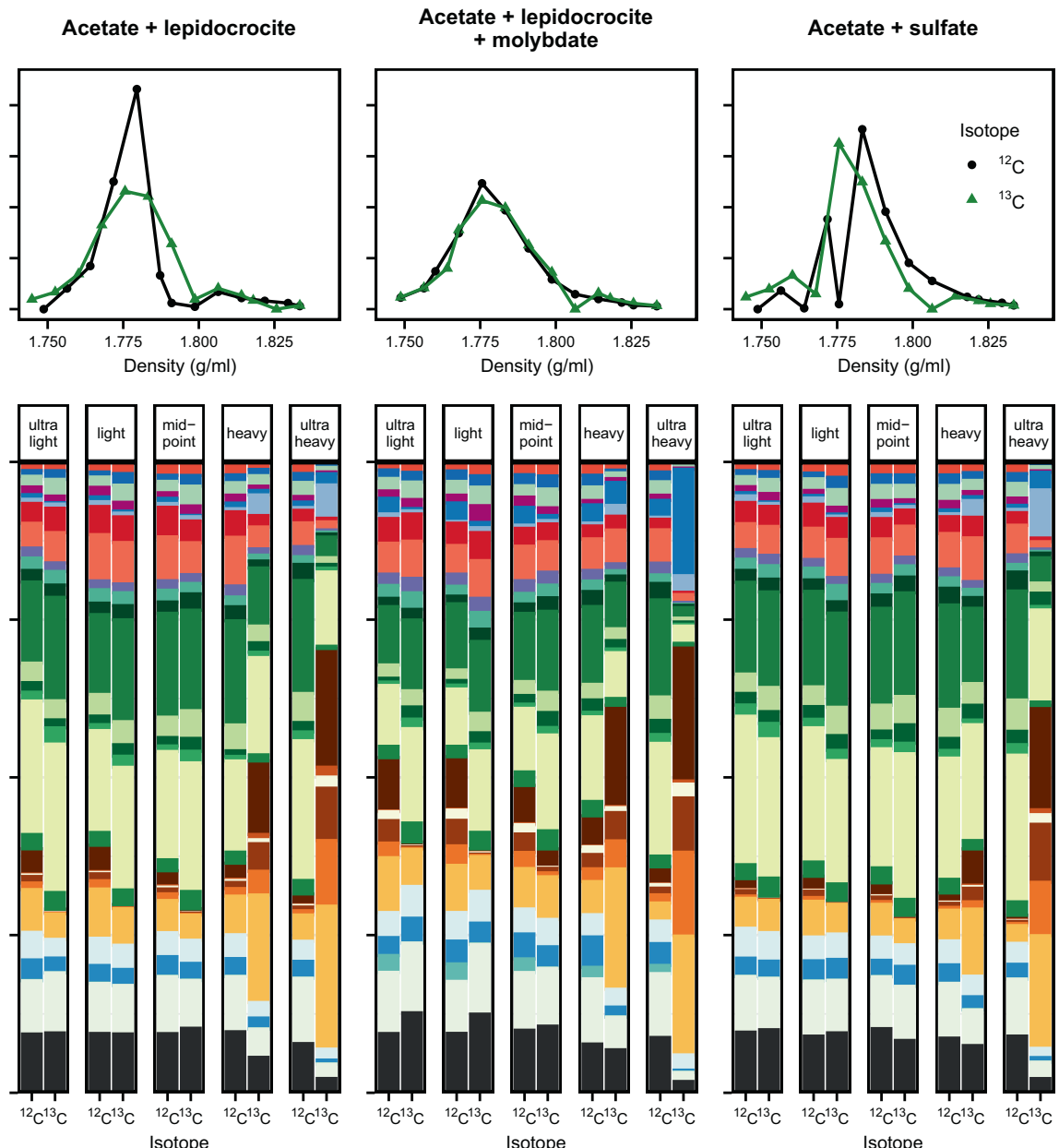

ultra light mid- heave uitra
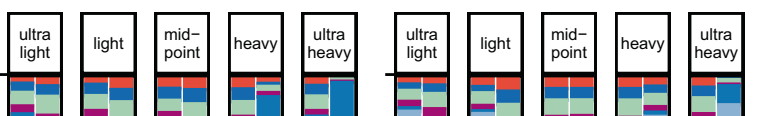

(1)
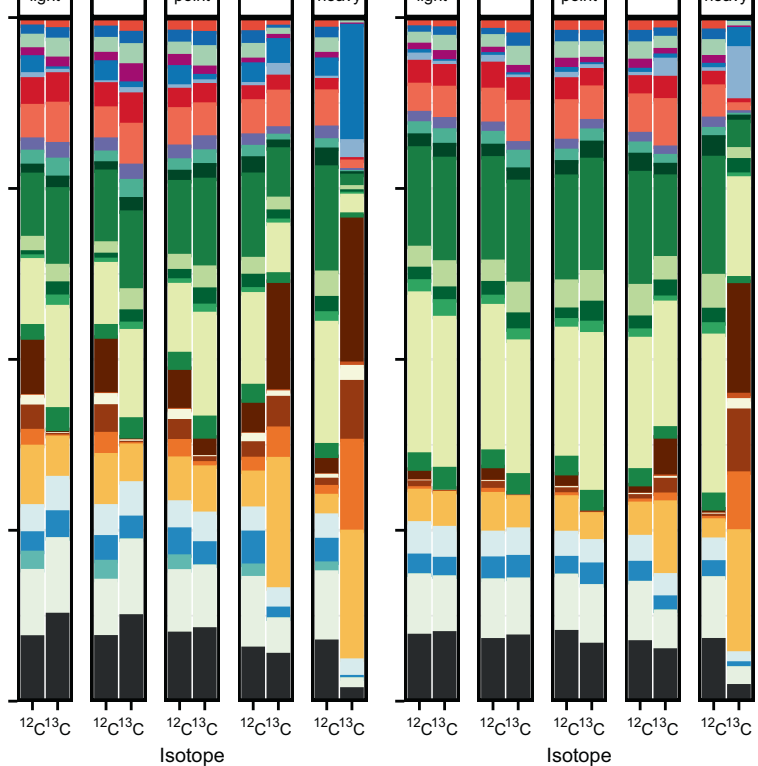

Isotope
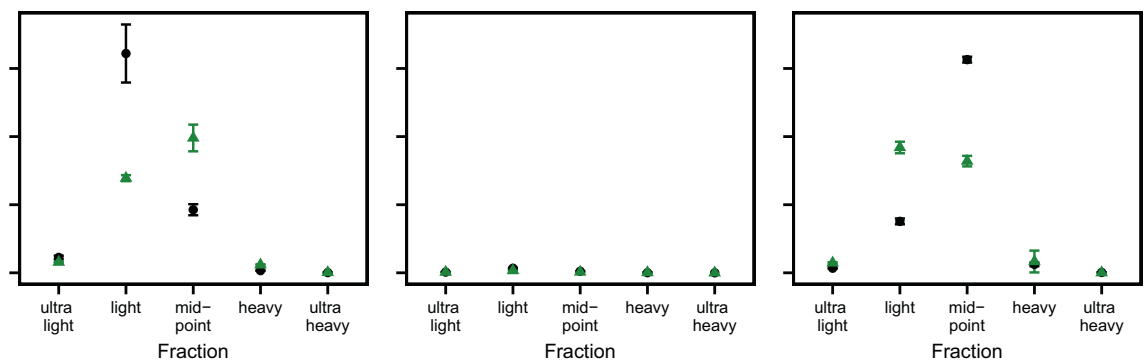

Phylum Proteobacteria

Alphaproteobacteria

Class Deltaproteobacteria

Desulfarculaceae (Desulfarculales) Order Desulfobacterales

SEEP-SRB1 (Desulfobacteraceae)

Sva0081 (Desulfobacteraceae)

other Desulfobacteraceae

Desulfobulbus (Desulfobulbaceae)

Desulfocapsa (Desulfobulbaceae) other Desulfobulbaceae

Sva0485

$$
\begin{aligned}
& \text { Order Desulfuromonadales } \\
& \text { Desulfuromonas (Desulfuromonadaceae) } \\
& \text { Malonomonas (Desulfuromonadaceae) } \\
& \text { other Desulfuromonadaceae } \\
& \text { Geopsychrobacter (Geobacteraceae) } \\
& \text { Geothermobacter (Geobacteraceae) } \\
& \text { Sva1033 } \\
& \text { other Deltaproteobacteria } \\
& \text { Class Gammaproteobacteria (Proteobacteria) } \\
& \text { B2M28 } \\
& \text { Nitrincolaceae (Oceanospirillales) } \\
& \text { other Gammaproteobacteria } \\
& \text { other Bacteria < } 2 \%
\end{aligned}
$$

Fig. 6 Results of SIP incubation with Cumberland Bay sediment. A Visualization of RNA density separation with normalized RNA amount (ng RNA in fraction per total recovered ng RNA of sample). B Density separated 16S rRNA community composition. C $d s r A$ transcript copies per ng cDNA from recovered RNA per fraction with
$\mathrm{SD}$ of technical qPCR replicates as error bars. In the molybdateamended treatment, the transcript copies were below detection limit ( $<100$ copies) for the ultra-heavy fraction and highest in the light fraction with $3000\left({ }^{13} \mathrm{C}\right)$ to $6700\left({ }^{12} \mathrm{C}\right)$ copies per ng cDNA from recovered RNA. Legend of $\mathbf{A}$ corresponds to $\mathbf{C}$. 
A

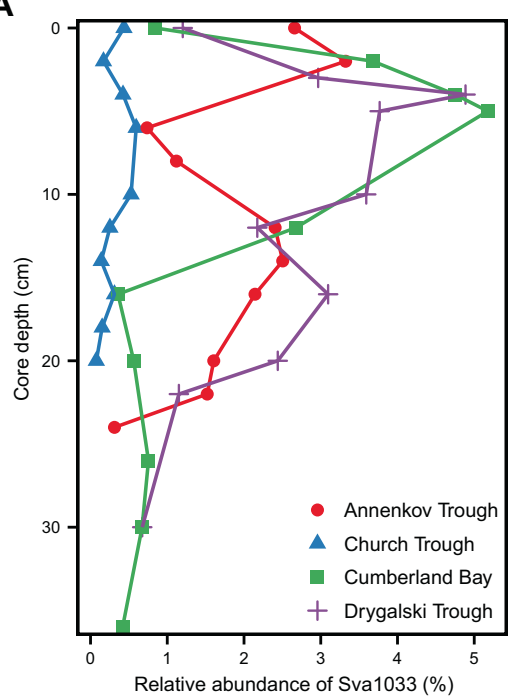

B

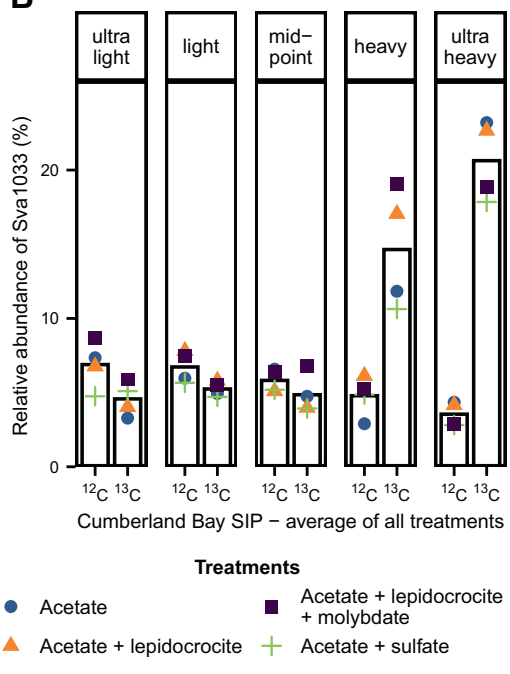

C

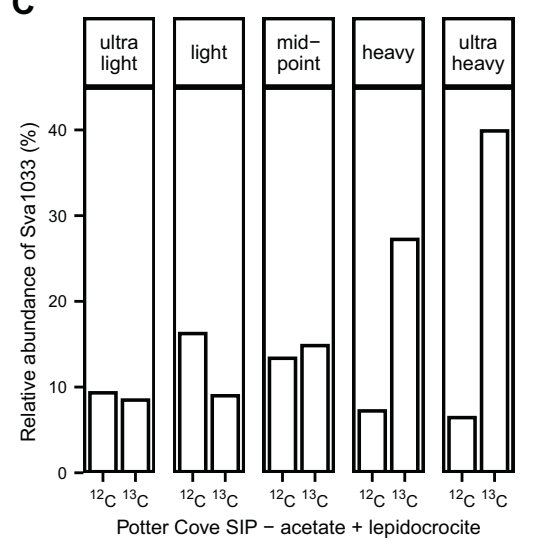

Fig. 7 Abundance and activity of Sva1033. Relative abundance of Sva1033 in South Georgia surface sediments (A) and in SIP incubations with Cumberland Bay (B) and Potter Cove sediment $(\mathbf{C})$. A Separation between sites by color and shape. B Averaged relative abundance of Sva1033 across all SIP treatments displayed by bars while relative abundance of each treatment is individually displayed by data points distinguishable by shape and color. copies/ng cDNA from recovered RNA per fraction) compared to the other treatments (up to 300000 transcript copies/ng cDNA per fraction). Sulfur oxidizing bacteria, Arcobacter and Sulfurimonas [87, 88] were the other enriched taxa in the ultra-heavy fractions. Arcobacter was mainly enriched in the ${ }^{13} \mathrm{C}$ acetate, lepidocrocite, and molybdate treatment $(17 \%)$ while Sulfurimonas was enriched in the treatments with acetate and lepidocrocite or sulfate $(5-8 \%)$.

In addition to SIP incubations with surface sediments from Cumberland Bay, a SIP treatment amended with acetate and lepidocrocite was set up with sediments from Potter Cove, Antarctica, as a geochemically similar site in order to compare iron reducing communities from different locations. SIP was performed after running the incubation for 10 days from which iron reduction was observed (Fig. S8C). The most dominant enriched taxon in the ${ }^{13} \mathrm{C}$ ultra-heavy fraction was the family Sva1033 (40\% of bacterial 16S rRNA genes; Figs. 7C and S9), a similar observation to the SIP incubations with sediments from Cumberland Bay.

In order to investigate the phylogenetic relations of the most-enriched taxon Sva1033 (Fig. 7), a phylogenetic tree was constructed with the closest neighbors to the most abundant OTUs assigned as Sva1033 in South Georgia in situ sediments and Cumberland Bay SIP incubations and the closest neighboring clades from the Silva ARB tree (release 138). OTUs detected in situ were closely related to OTUs detected in the SIP experiment (Fig. S7). The clade closest related to the family Sva1033 was "Desulfuromonas 2" (as assigned by Silva 138).

\section{Discussion}

Permanently cold coastal sediments from sub-Antarctic and Antarctic regions are subject to increased input of iron and other terrigenous compounds as a consequence of intensified weathering, erosion, and glacial melt due to observed global warming $[10-15,89,90]$. The impact of these altered element and material flux on the microbial communities in such sediments is currently understudied. Likewise, the bacterial communities present in surface sediments around the sub-Antarctic island South Georgia were not previously studied in detail. This study investigated the impact of environmental change on microbial communities in permanently cold (sub-)Antarctic sediments. Our findings show how geochemical characteristics such as the predominant electron accepting process and quality of organic matter potentially shape sediment communities in various sites around South Georgia. Importantly, in the iron reduction sites, we obtained evidence for dissimilatory iron reduction as one of Sva1033 clade's ecological roles in permanently cold sediments using RNA-SIP. Finally, indications for concurrent sulfate reduction were obtained, despite the dominance of iron reduction in incubation experiments.

\section{Geochemical footprints shape microbial community composition}

Selective survival of taxa buried below the upper $10 \mathrm{~cm}$ bioturbation zone has been identified as the significant process relevant for microbial community assembly in 
marine sediments [91-94]. Using the geochemical parameters as environmental factors for selection of the microbial community composition in the dbRDA (Figs. 4 and S5), various trends were observed. For example, depth-wise variation in community composition across all sites was strongly explained by the ammonium concentrations (Fig. 4), whose presence-along with DIC-is an indicator for organic matter degradation [95]. This was reflected in the core microbial community; the taxa Flavobacteriales, Rhodobacterales, Cellvibrionales, and Verrucomicrobiales, known for degradation of labile organic matter such as proteins, amino acids, polysaccharides, and simple sugars [96-99], were more abundant in the surface and decreased with depth across all sites (Fig. 3A). A similar trend was previously observed for some of these taxa in sediments of the Antarctic shelf [100]. In contrast, known "persister" microorganisms [91-93] such as Anaerolineae, Phycisphaerae, and the Atribacteria clade JS1 [101-104], showed a consistent increase in relative abundance along increasing depth across all sites (Fig. 3A). Differing supply of fresh organic matter on the outer shelf sites (Church Trough and Annenkov Trough) compared to sites located closer to the island was a possible explanation for likely higher microbial activity at these sites, as corroborating data from the geochemical profiles and gene copy numbers of microorganisms in the sediments (Figs. 2, 3B, 5, and S4B) indicated. This idea was supported by known large phytoplankton blooms and high primary production on the outer shelves around South Georgia [37, 40, 105].

Beyond ammonium shaping the communities along the sediment depth gradient, the dbRDA similarly showed a distinct selection of microbial communities in the study sites based on ferrous iron and sulfide concentrations. Thus, the likely dominant TEAP, i.e., iron and sulfate reduction, served as a factor for identifying the sites as either a group of iron reduction sites (Annenkov Trough, Cumberland Bay, Drygalski Trough) or sulfate reduction site (Church Trough; Fig. 4). A strong dependency of microbial community composition on TEAP was previously demonstrated in deeper sediments (down to $10 \mathrm{~m}$ below seafloor) from South Georgia [42] and from the Baffin Bay in the Arctic [27], in which iron and sulfate or iron and manganese reduction dominated, respectively.

Since ferrous iron and sulfide as products of microbial iron and sulfate reduction, respectively, were recognized by dbRDA as the environmental factors in our sediments to shape local communities, we hypothesize that the microorganisms contributing to these processes are important members of the microbial community. Thus identification of potential sulfate and iron reducers in the sediments will reveal which microorganisms are likely involved in the terminal respiratory processes. Amongst the sulfate reducers (Fig. 5), Desulfobacteraceae, Desulfobulbaceae, and
Desulfarculaceae were most dominant, even down to the deeper layers of Cumberland Bay and Church Trough sediments [42]. The order Desulfuromonadales harbors many species with the metabolic capability to perform dissimilatory iron reduction [74, 75, 77], but also sulfur reduction [106-110] and even a few microorganisms are capable of sulfate reduction [111]. Members of Desulfuromonadales are typically found in ferruginous sediments (e.g., [45, 112, 113]). This order was the most abundant potential dissimilatory iron reducing clade in this study. Here, the main representative identified was the family Sva1033 (Figs. 3A, 7A, and S6), which was recently suggested to be capable of iron reduction in a Terrestrial Mud Volcano site [82] and Arctic sediments [112]. Based on the calculated phylogenetic tree (Fig. S7), this family is closely related to the clade "Desulfuromonas 2" (as assigned by Silva release 138 [64]). Until now, there are no cultivated members of this clade and its metabolic capabilities are yet to be confirmed. The significant correlation between depthwise $\mathrm{Fe}^{2+}$ concentrations with relative abundance of Sva1033 in Annenkov Trough and Drygalski Trough (Fig. S6) strengthens the hypothesis that Sva1033 is involved in microbial iron reduction in surface sediments of South Georgia.

\section{The Sva1033 clade is capable of dissimilatory iron reduction}

As the Sva1033 clade was first identified in Arctic sediments [114], we tested the hypothesis that this clade is ecologically adapted to perform iron reduction as one of its metabolic capabilities in permanently cold sediments. This was done by setting up RNA-SIP incubations using acetate as labeled substrate with Cumberland Bay and Antarctic Potter Cove sediments, especially as both Potter Cove and Cumberland Bay are characterized by a broad ferruginous zone [14]. Due to thermodynamic constraints in dissimilatory utilization, acetate has been frequently used successfully for specifically tracing anaerobically respiring microorganisms such as iron reducers (e.g., [78, 86]). Within Cumberland Bay sediments, iron reduction is very likely the dominant TEAP occurring in all SIP incubations as indicated by the increasing $\mathrm{Fe}^{2+}$ concentrations in the treatments, including controls (Fig. S8A). The slurry likely retained endogenous iron oxides and organic matter from the original sediment. In surface sediments from Cumberland Bay (same sampling site but previous expedition), total $\mathrm{Fe}$ content of the solid phase of $46.8 \mathrm{~g} / \mathrm{kg}$ was reported [38], of which ferrihydrite and lepidocrocite contributed $0.65-0.7$ wt $\%$ Fe [39]. Therefore, iron reduction could be stimulated without the amendment of additional electron acceptors or donors (see unamended control treatment, Fig. S8A). Given the similarity in the microbial community 
composition and proportion of enriched taxa in the heavy fractions (Fig. 6B), we conclude that dissimilatory iron reduction is the most likely dominant process conducted by the labeled taxa enriched in the heavy fractions of all treatments, i.e., members of Desulfuromonadales with Sva1033 as the most abundant taxon. This conclusion was supported by the observed similar geochemistry in the treatments (Fig. S8). The possibility that other processes such as sulfate and sulfur reduction, which could occur in these incubations, stimulated the enrichment of Desulfuromonadales is not supported by the formation of $\mathrm{Fe}^{2+}$ in the incubation experiment over time (Fig. S8A). The likelihood that Sva1033 performs iron reduction in situ as in the RNASIP incubations is supported by the close relation of OTU sequences from the in situ sediment and the SIP experiment (Fig. S7). Likewise, in Potter Cove sediment incubations, Sva1033 was also identified as the most dominant organism taking up the acetate label (40\% relative abundance in ultra-heavy fraction, Figs. 7C and S9). Our study thus provides evidence for the capability for microbial iron reduction in the uncultured Sva1033 clade from permanently cold (sub-)Antarctic sediments with acetate as electron donor and carbon substrate (Fig. 7). Other taxa enriched in the heavy fractions of the SIP experiments included Desulfuromonas, Geopsychrobacter, and Geothermobacter, species with known iron reducing capabilities $[75,80,115,116]$.

\section{Activity of sulfate reducers in the iron reduction sites}

Sulfate reducers are metabolically flexible. Their primary metabolic capabilities are essential for the global sulfur cycle as utilizers of the most oxidized form of sulfur [117] and they are capable of syntrophic growth, e.g., with methanogens $[118,119]$. In addition, sulfate reducers are capable of growth with TEAPs such as nitrate $[84,120]$ and $\mathrm{Fe}(\mathrm{III})$ under sulfate limitation [83, 121]. In similar permanently cold marine sediments from the Arctic, sulfate reducers were relatively less abundant compared to iron reducers when iron reduction predominated [27, 112], which is in contrast to this study (Fig. 5). Despite the high abundance of sulfate reducers in the sediments of the ironrich sites (Figs. 3 and 5), evidence for sulfate reduction was not directly obtained from the pore water profiles (Fig. 2). Hence, an open question emerges regarding the metabolism that keeps sulfate reducers persistent across these sites such that their relative abundances outnumber the iron reducers who likely perform the clearly more dominant TEAP in situ (Fig. 2). We hypothesize for our study that sulfate reduction, masked by the reoxidation of the produced sulfide back to sulfate, fuels the persistence of sulfate reducers $[19,21]$ in the iron reduction sites.
The results from SIP incubations showed that sulfate reducers were present and active in all treatments. However, they were present in higher abundance in the light compared to the heavy fractions (Fig. 6B). This can be explained by their high abundance in the starting sediment material $(42 \%$, Fig. S10). Sulfate reducers responded to the addition of electron acceptor as evidenced by their increased relative abundance in the heavy fractions of the sulfate-amended treatment compared to the other treatments $(25 \%$ vs. $7-18 \%$ ultra-heavy labeled fraction). In general, the lower enrichment of sulfate reducers in the heavy fractions compared to the potential iron reducers is likely because (I) iron reducers were more efficient in the uptake of electron donors such as the provided acetate [122]; (II) iron reduction was the dominant biogeochemical process observed (as discussed above, Fig. 6B and S8A); or/and (III) sulfate reducers were thriving on different, sediment endogenous electron donors [123]. Nevertheless, the detection of $d s r A$ transcripts in the SIP fractions (Fig. 6C) supported the hypothesis of cooccurring sulfate reduction in the treatments. Following the observations of the SIP experiment, we suggest that minor concurrent sulfate reduction, in the background of the dominant TEAP i.e. iron reduction, likely fuels the persistence of sulfate reducers in situ in the iron reduction sites Annenkov Trough, Cumberland Bay, and Drygalski Trough (Figs. 3A and 5). The non-detection of sulfide in the incubations could be explained by precipitation with $\mathrm{Fe}^{2+}$ forming mackinawite $(\mathrm{FeS})$ and/or pyrite $\left(\mathrm{FeS}_{2}\right)[124,125]$, or reoxidation microbially or abiotically by reactive $\mathrm{Fe}(\mathrm{III})$ oxides [21]. Recently, this type of cryptic sulfur cycling, indicated by high sulfide oxidation rates in surface sediments, was shown in multiple studies [21, 126, 127]. In addition, concurrent sulfate and iron reduction in the same zone was reported multiple times [17, 20, 77, 124], but detailed information about the associated microbial community is lacking. These studies [21, 126-129] assign the majority of ferrous iron production to the abiotic process of iron reduction by sulfide oxidation. Although this process likely also occurs in the sediments investigated in this study, sulfide concentrations below detection limit (Fig. 2) and the high activity of mainly iron reducing microorganisms (Fig. 6B) indicate that these abiotic processes provide a minor contribution to observed high $\mathrm{Fe}^{2+}$ concentrations (Figs. 2 and S8A).

A limitation of our study is the unexpected lack of dissolved $\mathrm{Fe}^{2+}$ over time in the acetate, lepidocrocite and molybdate treatment from the SIP incubation (Fig. S8A). While this result suggested that iron reduction did not occur in this treatment, the enrichment of Desulfuromonadales members in similar proportion as in the other treatments shows that iron reduction certainly occurred (Fig. 6B). Besides, inhibition of iron reduction by molybdate has not been shown previously. In comparable studies, molybdate concentrations of $10 \mathrm{mM}$ [83] or even $20 \mathrm{mM}$ 
[124] did not inhibit microbial iron reduction. Instead, in our study, the produced dissolved $\mathrm{Fe}^{2+}$ reacted abiotically with the added molybdate, preventing the detection of $\mathrm{Fe}^{2+}$ (see supplementary material, Figs. S11 and S12, for details).

\section{Conclusion}

This study has shown how the microbial communities in subAntarctic South Georgia surface sediments are shaped by the dominant TEAP; sulfate reduction in Church Trough and iron reduction in Cumberland Bay, Drygalski Trough, and Annenkov Trough. We provide evidence for microbial iron reduction as one of the metabolic capabilities of the family Sva1033 using RNA-SIP with Cumberland Bay surface sediments. Coincidentally, in all iron reduction sites, Sva1033 was the dominant member of Desulfuromonadales found in situ, while other known marine iron reducers were scarce. We also identified iron-reducing capabilities of Sva1033 members in similar surface sediments from Potter Cove in the Antarctic Peninsula. Therefore, this clade might be very important for iron reduction in permanently cold marine sediments given the input of iron from enhanced glacial erosion, weathering, and glacial melt as a result of global warming. Furthermore, our data show high relative abundance of persistent sulfate reducers and suggest their activity in the iron reduction zone of marine sediments potentially participating in cryptic sulfur cycling, with the produced sulfide precipitating as metal sulfide mineral or being reoxidized.

\section{Data availability}

The raw sequence data of this study were submitted to GenBank Short Reads Archive (SRA) under the BioProject numbers PRJNA658241 and PRJNA668691 (BioSample numbers SAMN16419039-SAMN16419043 and SAMN16419024-SAMN16419028). The environmental geochemical data were submitted to PANGAEA data publisher for Earth \& Environmental Science database under the following doi: 10.1594/PANGAEA.927101.

\begin{abstract}
Acknowledgements The authors thank the captain and entire shipboard crew of the RV METEOR M134 research expedition to South Georgia in January to February 2017. The authors also thank the Alfred Wegener Institute Helmholtz Centre for Polar and Marine Research and the Instituto Antártico Argentino (IAA) for logistical support during the Antarctic summer sampling campaign (January to March 2019) to the King George Island/Isla 25 de Mayo in the Antarctic Peninsula. The authors also thank the crew at the Argentinian Research Station Base Carlini and the Argentinian Army (Ejército Argentino) divers of the CAV (January to March 2019) for logistics support during the campaign.
\end{abstract}

Funding This project was funded by the Deutsche Forschungsgemeinschaft (DFG) Research Center/Cluster of Excellence
EXC 309 (project-ID 49926684) "The Ocean in the Earth System," and within the DFG infrastructure priority program 1158 "Antarctic Research with Comparative Investigations in Arctic Ice Areas" (project-ID 404648014), and the University of Bremen. The expedition under the title "Emissions of free gas around South Georgia: distribution, quantification, and sources for methane ebullition sites in sub-Antarctic waters" was carried out with the support of MARUM Center for Marine Environmental Sciences, Research Faculty University of Bremen. We also acknowledge additional funding from the Helmholtz Association (Alfred Wegener Institute Helmholtz Centre for Polar and Marine Research, Bremerhaven). The cruise was sponsored by the German Research Foundation (DFG) and by the Federal Ministry of Education and Research (BMBF). Open Access funding enabled and organized by Projekt DEAL.

\section{Compliance with ethical standards}

Conflict of interest The authors declare no competing interests.

Publisher's note Springer Nature remains neutral with regard to jurisdictional claims in published maps and institutional affiliations.

Open Access This article is licensed under a Creative Commons Attribution 4.0 International License, which permits use, sharing, adaptation, distribution and reproduction in any medium or format, as long as you give appropriate credit to the original author(s) and the source, provide a link to the Creative Commons license, and indicate if changes were made. The images or other third party material in this article are included in the article's Creative Commons license, unless indicated otherwise in a credit line to the material. If material is not included in the article's Creative Commons license and your intended use is not permitted by statutory regulation or exceeds the permitted use, you will need to obtain permission directly from the copyright holder. To view a copy of this license, visit http://creativecommons. org/licenses/by/4.0/.

\section{References}

1. D’Hondt S, Jørgensen BB, Miller DJ, Batzke A, Blake R, Cragg BA, et al. Distributions of microbial activities in deep subseafloor sediments. Science. 2004;306:2216-21.

2. Froelich PN, Klinkhammer GP, Bender ML, Luedtke NA, Heath GR, Cullen D, et al. Early oxidation of organic matter in pelagic sediments of the eastern equatorial Atlantic: suboxic diagenesis. Geochim Cosmochim Acta. 1979;43:1075-90.

3. Parkes RJ, Cragg B, Roussel E, Webster G, Weightman A, Sass H. A review of prokaryotic populations and processes in subseafloor sediments, including biosphere: geosphere interactions. Mar Geol. 2014;352:409-25.

4. Arnosti C. Microbial extracellular enzymes and the marine carbon cycle. Annu Rev Mar Sci. 2011;3:401-25.

5. Thamdrup B, Rosselló-Mora R, Amann R. Microbial manganese and sulfate reduction in Black Sea shelf sediments. Appl Environ Microbiol. 2000;66:2888-97.

6. Thamdrup B. Bacterial manganese and iron reduction in aquatic sediments. In: Schink B, editor. Advances in microbial ecology. Boston, MA, US: Springer; 2000. p. 41-84.

7. Jørgensen BB, Kasten S. Sulfur cycling and methane oxidation. In: Schulz HD, Zabel M, editors. Marine geochemistry. 2nd ed. Berlin, Heidelberg, Germany: Springer-Verlag; 2006. p. 271-309.

8. Bowles MW, Mogollón JM, Kasten S, Zabel M, Hinrichs K-U. Global rates of marine sulfate reduction and implications for sub-sea-floor metabolic activities. Science. 2014;344:889-91. 
9. Jickells TD, An ZS, Andersen KK, Baker AR, Bergametti G, Brooks N, et al. Global iron connections between desert dust, ocean biogeochemistry, and climate. Science. 2005;308:67-71.

10. Raiswell R, Hawkings JR, Benning LG, Baker AR, Death R, Albani S, et al. Potentially bioavailable iron delivery by iceberghosted sediments and atmospheric dust to the polar oceans. Biogeosciences. 2016;13:3887-900.

11. Hawkings JR, Wadham JL, Tranter M, Raiswell R, Benning LG, Statham PJ, et al. Ice sheets as a significant source of highly reactive nanoparticulate iron to the oceans. Nat Commun. 2014;5:3929.

12. Death R, Wadham JL, Monteiro F, Le Brocq AM, Tranter M, Ridgwell A, et al. Antarctic ice sheet fertilises the Southern Ocean. Biogeosciences. 2014;11:2635-43.

13. Monien D, Monien P, Brünjes R, Widmer T, Kappenberg A, Silva Busso AA, et al. Meltwater as a source of potentially bioavailable iron to Antarctica waters. Antarct Sci. 2017;29:277-91.

14. Henkel S, Kasten S, Hartmann JF, Silva-Busso A, Staubwasser $\mathrm{M}$. Iron cycling and stable $\mathrm{Fe}$ isotope fractionation in Antarctic shelf sediments, King George Island. Geochim Cosmochim Acta. 2018;237:320-38.

15. Hodson A, Nowak A, Sabacka M, Jungblut A, Navarro F, Pearce $\mathrm{D}$, et al. Climatically sensitive transfer of iron to maritime Antarctic ecosystems by surface runoff. Nat Commun. 2017;8: 14499.

16. Wang S, Bailey D, Lindsay K, Moore JK, Holland M. Impact of sea ice on the marine iron cycle and phytoplankton productivity. Biogeosciences. 2014;11:4713-31.

17. Jørgensen BB, Findlay AJ, Pellerin A. The biogeochemical sulfur cycle of marine sediments. Front Microbiol. 2019;10:849.

18. Findlay AJ, Kamyshny A. Turnover rates of intermediate sulfur species $\left(\mathrm{S}_{\mathrm{x}}{ }^{2-}, \mathrm{S}^{0}, \mathrm{~S}_{2} \mathrm{O}_{3}{ }^{2-}, \mathrm{S}_{4} \mathrm{O}_{6}{ }^{2-}, \mathrm{SO}_{3}{ }^{2-}\right)$ in anoxic freshwater and sediments. Front Microbiol. 2017;8:2551.

19. Findlay AJ, Pellerin A, Laufer K, Jørgensen BB. Quantification of sulphide oxidation rates in marine sediment. Geochim Cosmochim Acta. 2020;280:441-52.

20. Canfield DE, Jørgensen BB, Fossing H, Glud R, Gundersen J, Ramsing NB, et al. Pathways of organic carbon oxidation in three continental margin sediments. Mar Geol. 1993;113:27-40.

21. Michaud AB, Laufer K, Findlay A, Pellerin A, Antler G, Turchyn AV, et al. Glacial influence on the iron and sulfur cycles in Arctic fjord sediments (Svalbard). Geochim Cosmochim Acta. 2020;280:423-40.

22. Jensen MM, Thamdrup B, Rysgaard S, Holmer M, Fossing H. Rates and regulation of microbial iron reduction in sediments of the Baltic-North Sea transition. Biogeochemistry. 2003;65:295-317.

23. Beckler JS, Kiriazis N, Rabouille C, Stewart FJ, Taillefert M. Importance of microbial iron reduction in deep sediments of river-dominated continental-margins. Mar Chem. 2016;178: 22-34.

24. Riedinger N, Brunner B, Krastel S, Arnold GL, Wehrmann LM, Formolo MJ, et al. Sulfur cycling in an iron oxide-dominated, dynamic marine depositional system: the Argentine Continental Margin. Front Earth Sci. 2017;5:33.

25. Thamdrup B, Fossing H, Jørgensen BB. Manganese, iron and sulfur cycling in a coastal marine sediment, Aarhus Bay, Denmark. Geochim Cosmochim Acta. 1994;58:5115-29.

26. Arndt S, Jørgensen BB, LaRowe DE, Middelburg J, Pancost R, Regnier P. Quantifying the degradation of organic matter in marine sediments: a review and synthesis. Earth-Sci Rev. 2013;123:53-86.

27. Algora C, Vasileiadis S, Wasmund K, Trevisan M, Krüger M, Puglisi E, et al. Manganese and iron as structuring parameters of microbial communities in Arctic marine sediments from the Baffin Bay. FEMS Microbiol Ecol. 2015;91:fiv056.
28. Franco M, De Mesel I, Diallo MD, Van Der Gucht K, Van Gansbeke D, Van, et al. Effect of phytoplankton bloom deposition on benthic bacterial communities in two contrasting sediments in the southern North Sea. Aquat Micro Ecol. 2007;48:241-54.

29. Zonneveld KAF, Versteegh GJM, Kasten S, Eglinton TI, Emeis $\mathrm{K}-\mathrm{C}$, Huguet $\mathrm{C}$, et al. Selective preservation of organic matter in marine environments; processes and impact on the sedimentary record. Biogeosciences. 2010;7:483-511.

30. Jorgensen SL, Hannisdal B, Lanzén A, Baumberger T, Flesland $\mathrm{K}$, Fonseca R, et al. Correlating microbial community profiles with geochemical data in highly stratified sediments from the Arctic Mid-Ocean Ridge. Proc Natl Acad Sci U S A. 2012;109: E2846-55.

31. Zinke LA, Glombitza C, Bird JT, Røy H, Jørgensen BB, Lloyd KG, et al. Microbial organic matter degradation potential in Baltic Sea sediments is influenced by depositional conditions and in situ geochemistry. Appl Environ Microbiol. 2019;85: e02164-18.

32. Yang J, Jiang H, Wu G, Dong H. Salinity shapes microbial diversity and community structure in surface sediments of the Qinghai-Tibetan Lakes. Sci Rep. 2016;6:25078.

33. Hicks N, Liu X, Gregory R, Kenny J, Lucaci A, Lenzi L, et al. Temperature driven changes in benthic bacterial diversity influences biogeochemical cycling in coastal sediments. Front Microbiol. 2018;9:1730.

34. Hamdan LJ, Coffin RB, Sikaroodi M, Greinert J, Treude T, Gillevet PM. Ocean currents shape the microbiome of Arctic marine sediments. ISME J. 2013;7:685-96.

35. Schulz HD, Zabel M, editors. Marine geochemistry. 2nd ed. Berlin, Heidelberg, Germany: Springer-Verlag; 2006.

36. Geprägs P, Torres ME, Mau S, Kasten S, Römer M, Bohrmann G. Carbon cycling fed by methane seepage at the shallow Cumberland Bay, South Georgia, sub-Antarctic. Geochem, Geophys Geosystems. 2016;17:1401-18.

37. Atkinson A, Whitehouse MJ, Priddle J, Cripps GC, Ward P, Brandon MA. South Georgia, Antarctica: a productive, cold water, pelagic ecosystem. Mar Ecol Prog Ser. 2001;216: 279-308.

38. Löffler B. Geochemische Prozesse und Stoffkreisläufe in Sedimenten innerhalb und außerhalb des Cumberland-Bay Fjordes, Süd Georgien. Bachelor Thesis. Bremen, Germany: University of Bremen; 2013.

39. Köster M. (Bio-)geochemische Prozesse in den eisenreichen Seep-Sedimenten der Cumberland-Bucht Südgeorgiens, Subantarktis. Bachelor Thesis. Bremen, Germany: University of Bremen; 2014.

40. Römer M, Torres M, Kasten S, Kuhn G, Graham AG, Mau S, et al. First evidence of widespread active methane seepage in the Southern Ocean, off the sub-Antarctic island of South Georgia. Earth Planet Sci Lett. 2014;403:166-77.

41. Bohrmann G, Aromokeye AD, Bihler V, Dehning K, Dohrmann I, Gentz T, et al. R/V METEOR Cruise Report M134, emissions of free gas from cross-shelf troughs of South Georgia: distribution, quantification, and sources for methane ebullition sites in sub-Antarctic waters, Port Stanley (Falkland Islands)—Punta Arenas (Chile), 16 January-18 February 2017. 2017.

42. Schnakenberg A, Aromokeye DA, Kulkarni A, Maier L, Wunder LC, Richter-Heitmann T, et al. Electron acceptor availability shapes Anaerobically Methane Oxidizing Archaea (ANME) communities in South Georgia sediments. Front Microbiol. 2021;12:726.

43. Rückamp M, Braun M, Suckro S, Blindow N. Observed glacial changes on the King George Island ice cap, Antarctica, in the last decade. Global Planet Change. 2011;79:99-109. 
44. Seeberg-Elverfeldt J, Schlüter M, Feseker T, Kölling M. Rhizon sampling of porewaters near the sediment-water interface of aquatic systems. Limnol Oceanogr Methods. 2005;3:361-71.

45. Oni OE, Miyatake T, Kasten S, Richter-Heitmann T, Fischer D, Wagenknecht L, et al. Distinct microbial populations are tightly linked to the profile of dissolved iron in the methanic sediments of the Helgoland mud area, North Sea. Front Microbiol. 2015;6:365.

46. Aromokeye DA, Richter-Heitmann T, Oni OE, Kulkarni A, Yin $\mathrm{X}$, Kasten S, et al. Temperature controls crystalline iron oxide utilization by microbial communities in methanic ferruginous marine sediment incubations. Front Microbiol. 2018;9:2574.

47. Parada AE, Needham DM, Fuhrman JA. Every base matters: assessing small subunit rRNA primers for marine microbiomes with mock communities, time series and global field samples. Environ Microbiol. 2016;18:1403-14.

48. Herlemann DPR, Labrenz M, Jürgens K, Bertilsson S, Waniek JJ, Andersson AF. Transitions in bacterial communities along the $2000 \mathrm{~km}$ salinity gradient of the Baltic Sea. ISME J. 2011;5:1571-9.

49. Ovreås L, Forney L, Daae FL, Torsvik V. Distribution of bacterioplankton in meromictic Lake Saelenvannet, as determined by denaturing gradient gel electrophoresis of PCR-amplified gene fragments coding for 16S rRNA. Appl Environ Microbiol. 1997;63:3367-73.

50. Takai K, Horikoshi K. Rapid detection and quantification of members of the archaeal community by quantitative PCR using fluorogenic probes. Appl Environ Microbiol. 2000;66:5066-72.

51. Viollier E, Inglett $P$, Hunter K, Roychoudhury A, Van Cappellen P. The ferrozine method revisited: $\mathrm{Fe}(\mathrm{II}) / \mathrm{Fe}$ (III) determination in natural waters. Appl Geochem. 2000;15:785-90.

52. Yin X, Kulkarni AC, Friedrich MW. DNA and RNA stable isotope probing of methylotrophic methanogenic Archaea. In: Dumont MG, Hernández García M, editors. Stable isotope probing: methods and protocols. New York, NY: Springer; 2019. p. 189-206.

53. Aromokeye DA, Kulkarni AC, Elvert M, Wegener G, Henkel S, Coffinet S, et al. Rates and microbial players of iron-driven anaerobic oxidation of methane in methanic marine sediments. Front Microbiol. 2020;10:3041.

54. Eden PA, Schmidt TM, Blakemore RP, Pace NR. Phylogenetic analysis of Aquaspirillum magnetotacticum using polymerase chain reaction-amplified 16S rRNA-specific DNA. Int J Syst Evol Microbiol. 1991;41:324-5.

55. Yu Y, Lee C, Kim J, Hwang S. Group-specific primer and probe sets to detect methanogenic communities using quantitative realtime polymerase chain reaction. Biotechnol Bioeng. 2005;89: 670-9.

56. Lueders T, Friedrich MW. Effects of amendment with ferrihydrite and gypsum on the structure and activity of methanogenic populations in rice field soil. Appl Environ Microbiol. 2002;68:2484-94.

57. Lane DJ. 16S/23S rRNA sequencing. In: Stackebrandt E, Goodfellow M, editors. Nucleic acid techniques in bacterial systematics. New York: John Wiley and Sons; 1991. p. 115-75.

58. Großkopf R, Janssen PH, Liesack W. Diversity and structure of the methanogenic community in anoxic rice paddy soil microcosms as examined by cultivation and direct 16S rRNA gene sequence retrieval. Appl Environ Microbiol. 1998;64:960-9.

59. Reyes C, Schneider D, Thürmer A, Kulkarni A, Lipka M, Sztejrenszus SY, et al. Potentially active iron, sulfur, and sulfate reducing bacteria in Skagerrak and Bothnian Bay sediments. Geomicrobiol J. 2017;34:840-50.

60. Kondo R, Nedwell DB, Purdy KJ, Silva SQ. Detection and enumeration of sulphate-reducing Bacteria in estuarine sediments by competitive PCR. Geomicrobiol J. 2004;21:145-57.
61. Benjamini Y, Yekutieli D. The control of the false discovery rate in multiple testing under dependency. Ann Stat. 2001;29: 1165-88.

62. R Core Team. R: a language and environment for statistical computing, 3.6.1. Vienna, Austria: $\mathrm{R}$ Foundation for Statistical Computing; 2019. Available from: https://www.Rproject.org.

63. Oksanen J, Blanchet FG, Friendly M, Kindt R, Legendre P, McGlinn D, et al. vegan: Community Ecology Package, 2.5-6. 2019. Available from: https://CRAN.R-project.org/package= vegan.

64. Quast C, Pruesse E, Yilmaz P, Gerken J, Schweer T, Yarza P, et al. The SILVA ribosomal RNA gene database project: improved data processing and web-based tools. Nucleic Acids Res. 2012;41:D590-6.

65. Stamatakis A. RAxML version 8: a tool for phylogenetic analysis and post-analysis of large phylogenies. Bioinformatics. 2014;30:1312-3.

66. Letunic I, Bork P. Interactive Tree Of Life (iTOL) v4: recent updates and new developments. Nucleic Acids Res. 2019;47: W256-9.

67. Inkscape Team. Inkscape, 1.0.1. 2020. Available from: https:// inkscape.org.

68. Sun H, Spring S, Lapidus A, Davenport K, Glavina Del Rio T, Tice $\mathrm{H}$, et al. Complete genome sequence of Desulfarculus baarsii type strain (2st14T). Stand Genom Sci. 2010;3:276-84.

69. Kümmel S, Herbst F-A, Bahr A, Duarte M, Pieper DH, Jehmlich $\mathrm{N}$, et al. Anaerobic naphthalene degradation by sulfate-reducing Desulfobacteraceae from various anoxic aquifers. FEMS Microbiol Ecol. 2015;91:fiv006.

70. Belyakova EV, Rozanova EP, Borzenkov IA, Tourova TP, Pusheva MA, Lysenko AM, et al. The new facultatively chemolithoautotrophic, moderately halophilic, sulfate-reducing bacterium Desulfovermiculus halophilus gen. nov., sp. nov., isolated from an oil field. Microbiology. 2006;75:161-71.

71. Rezadehbashi M, Baldwin SA. Core sulphate-reducing microorganisms in metal-removing semi-passive biochemical reactors and the co-occurrence of methanogens. Microorganisms. 2018;6:16.

72. Sheik CS, Jain S, Dick GJ. Metabolic flexibility of enigmatic SAR324 revealed through metagenomics and metatranscriptomics. Environ Microbiol. 2014;16:304-17.

73. Sorokin DY, Chernyh NA. 'Candidatus Desulfonatronobulbus propionicus': a first haloalkaliphilic member of the order Syntrophobacterales from soda lakes. Extremophiles. 2016;20: 895-901.

74. Lovley DR, Giovannoni SJ, White DC, Champine JE, Phillips E, Gorby YA, et al. Geobacter metallireducens gen. nov. sp. nov., a microorganism capable of coupling the complete oxidation of organic compounds to the reduction of iron and other metals. Arch Microbiol. 1993;159:336-44.

75. Roden EE, Lovley DR. Dissimilatory Fe(III) reduction by the marine microorganism Desulfuromonas acetoxidans. Appl Environ Microbiol. 1993;59:734-42.

76. Lovley DR, Coates JD, Saffarini DA, Lonergan DJ. Dissimilatory iron reduction. In: Winkelmann G, Carrano CJ, editors. Transition metals in microbial metabolism. Amsterdam: Harwood Academic Publishers; 1997. p. 187-215.

77. Vandieken V, Finke N, Jørgensen BB. Pathways of carbon oxidation in an Arctic fjord sediment (Svalbard) and isolation of psychrophilic and psychrotolerant Fe(III)-reducing bacteria. Mar Ecol Prog Ser. 2006;322:29-41.

78. Vandieken V, Thamdrup B. Identification of acetate-oxidizing bacteria in a coastal marine surface sediment by RNA-stable isotope probing in anoxic slurries and intact cores. FEMS Microbiol Ecol. 2013;84:373-86. 
79. Hori T, Aoyagi T, Itoh H, Narihiro T, Oikawa A, Suzuki K, et al. Isolation of microorganisms involved in reduction of crystalline iron(III) oxides in natural environments. Front Microbiol. 2015;6:386.

80. Vandieken V, Mußmann M, Niemann H, Jørgensen BB. Desulfuromonas svalbardensis sp. nov. and Desulfuromusa ferrireducens sp. nov., psychrophilic, Fe(III)-reducing bacteria isolated from Arctic sediments, Svalbard. Int J Syst Evol Microbiol. 2006;56:1133-9.

81. Slobodkina GB, Reysenbach A-L, Panteleeva AN, Kostrikina NA, Wagner ID, Bonch-Osmolovskaya EA, et al. Deferrisoma camini gen. nov., sp. nov., a moderately thermophilic, dissimilatory iron(III)-reducing bacterium from a deep-sea hydrothermal vent that forms a distinct phylogenetic branch in the Deltaproteobacteria. Int J Syst Evol Microbiol. 2012;62:2463-8.

82. Tu T-H, Wu L-W, Lin Y-S, Imachi H, Lin L-H, Wang P-L. Microbial community composition and functional capacity in a terrestrial ferruginous, sulfate-depleted mud volcano. Front Microbiol. 2017;8:2137.

83. Lovley DR, Roden EE, Phillips EJP, Woodward JC. Enzymatic iron and uranium reduction by sulfate-reducing bacteria. Mar Geol. 1993;113:41-53.

84. Bale SJ, Goodman K, Rochelle PA, Marchesi JR, Fry JC, Weightman AJ, et al. Desulfovibrio profundus sp. nov., a novel barophilic sulfate-reducing Bacterium from deep sediment layers in the Japan Sea. Int J Syst Evol Microbiol. 1997;47:515-21.

85. Treude N, Rosencrantz D, Liesack W, Schnell S. Strain FAc12, a dissimilatory iron-reducing member of the Anaeromyxobacter subgroup of Myxococcales. FEMS Microbiol Ecol. 2003;44: 261-9.

86. Hori T, Müller A, Igarashi Y, Conrad R, Friedrich MW. Identification of iron-reducing microorganisms in anoxic rice paddy soil by ${ }^{13}$ C-acetate probing. ISME J. 2010;4:267-78.

87. Han Y, Perner M. The globally widespread genus Sulfurimonas: versatile energy metabolisms and adaptations to redox clines. Front Microbiol. 2015;6:989.

88. Roalkvam I, Drønen K, Stokke R, Daae FL, Dahle H, Steen IH. Physiological and genomic characterization of Arcobacter anaerophilus IR-1 reveals new metabolic features in Epsilonproteobacteria. Front Microbiol. 2015;6:987.

89. Schlosser C, Schmidt K, Aquilina A, Homoky WB, Castrillejo M, Mills RA, et al. Mechanisms of dissolved and labile particulate iron supply to shelf waters and phytoplankton blooms off South Georgia, Southern Ocean. Biogeosciences. 2018;15: 4973-93.

90. Sahade R, Lagger C, Torre L, Momo F, Monien P, Schloss I, et al. Climate change and glacier retreat drive shifts in an Antarctic benthic ecosystem. Sci Adv. 2015;1:e1500050.

91. Petro C, Starnawski P, Schramm A, Kjeldsen KU. Microbial community assembly in marine sediments. Aquat Micro Ecol. 2017;79:177-95.

92. Petro C, Zäncker B, Starnawski P, Jochum LM, Ferdelman TG, Jørgensen BB, et al. Marine deep biosphere microbial communities assemble in near-surface sediments in Aarhus Bay. Front Microbiol. 2019;10:758.

93. Starnawski P, Bataillon T, Ettema TJ, Jochum LM, Schreiber L, Chen X, et al. Microbial community assembly and evolution in subseafloor sediment. Proc Natl Acad Sci USA. 2017;114: 2940-5.

94. Marshall IPG, Ren G, Jaussi M, Lomstein BA, Jørgensen BB, $\mathrm{R} \varnothing \mathrm{y} \mathrm{H}$, et al. Environmental filtering determines family-level structure of sulfate-reducing microbial communities in subsurface marine sediments. ISME J. 2019;13:1920-32.

95. Berner RA. Early diagenesis: a theoretical approach. Princeton, New Jersey: Princeton University Press; 1980.
96. Cottrell MT, Kirchman DL. Natural assemblages of marine Proteobacteria and members of the Cytophaga-Flavobacter cluster consuming low- and high-molecular-weight dissolved organic matter. Appl Environ Microbiol. 2000;66:1692-7.

97. Bissett A, Bowman JP, Burke CM. Flavobacterial response to organic pollution. Aquat Micro Ecol. 2008;51:31-43.

98. Martinez-Garcia M, Brazel DM, Swan BK, Arnosti C, Chain PSG, Reitenga KG, et al. Capturing single cell genomes of active polysaccharide degraders: an unexpected contribution of Verrucomicrobia. PLoS ONE. 2012;7:e35314.

99. Sabree ZL, Kambhampati S, Moran NA. Nitrogen recycling and nutritional provisioning by Blattabacterium, the cockroach endosymbiont. Proc Natl Acad Sci U S A. 2009;106:19521-6.

100. Bowman JP, McCuaig RD. Biodiversity, community structural shifts, and biogeography of Prokaryotes within Antarctic continental shelf sediment. Appl Environ Microbiol. 2003;69: 2463-83.

101. Blazejak A, Schippers A. High abundance of JS-1- and Chloroflexi-related Bacteria in deeply buried marine sediments revealed by quantitative, real-time PCR. FEMS Microbiol Ecol. 2010;72:198-207.

102. Yamada T, Sekiguchi Y, Hanada S, Imachi H, Ohashi A, Harada $\mathrm{H}$, et al. Anaerolinea thermolimosa sp. nov., Levilinea saccharolytica gen. nov., sp. nov. and Leptolinea tardivitalis gen. nov., sp. nov., novel filamentous anaerobes, and description of the new classes Anaerolineae classis nov. and Caldilineae classis nov. in the bacterial phylum Chloroflexi. Int $\mathrm{J}$ Syst Evol Microbiol. 2006;56:1331-40.

103. Storesund JE, Øvreås L. Diversity of Planctomycetes in ironhydroxide deposits from the Arctic Mid Ocean Ridge (AMOR) and description of Bythopirellula goksoyri gen. nov., sp. nov., a novel Planctomycete from deep sea iron-hydroxide deposits. Antonie Van Leeuwenhoek. 2013;104:569-84.

104. Kovaleva OL, Merkel AY, Novikov AA, Baslerov RV, Toshchakov SV, Bonch-Osmolovskaya EA. Tepidisphaera mucosa gen. nov., sp. nov., a moderately thermophilic member of the class Phycisphaerae in the phylum Planctomycetes, and proposal of a new family, Tepidisphaeraceae fam. nov., and a new order, Tepidisphaerales ord. nov. Int $\mathbf{J}$ Syst Evol Microbiol. 2015;65:549-55.

105. Borrione I, Schlitzer R. Distribution and recurrence of phytoplankton blooms around South Georgia, Southern Ocean. Biogeosciences. 2013;10:217-31.

106. Pfennig N, Biebl H. Desulfuromonas acetoxidans gen. nov. and sp. nov., a new anaerobic, sulfur-reducing, acetate-oxidizing bacterium. Arch Microbiol. 1976;110:3-12.

107. Finster K, Bak F, Pfennig N. Desulfuromonas acetexigens sp. nov., a dissimilatory sulfur-reducing eubacterium from anoxic freshwater sediments. Arch Microbiol. 1994;161:328-32.

108. Lovley DR, Phillips EJP, Lonergan DJ, Widman PK. Fe(III) and $\mathrm{S}^{0}$ reduction by Pelobacter carbinolicus. Appl Environ Microbiol. 1995;61:2132-8.

109. An TT, Picardal FW. Desulfuromonas carbonis sp. nov., an $\mathrm{Fe}(\mathrm{III})-, \mathrm{S}^{0}$ - and $\mathrm{Mn}(\mathrm{IV})$-reducing bacterium isolated from an active coalbed methane gas well. Int J Syst Evol Microbiol. 2015;65:1686-93.

110. Pjevac P, Kamyshny A Jr, Dyksma S, Mußmann M. Microbial consumption of zero-valence sulfur in marine benthic habitats. Environ Microbiol. 2014;16:3416-30.

111. Miao Z-Y, He H, Tan T, Zhang T, Tang J-L, Yang Y-C, et al. Biotreatment of $\mathrm{Mn}^{2+}$ and $\mathrm{Pb}^{2+}$ with sulfate-reducing bacterium Desulfuromonas alkenivorans S-7. J Environ Eng. 2018;144: 04017116.

112. Buongiorno J, Herbert L, Wehrmann L, Michaud A, Laufer K, $\mathrm{R} ø \mathrm{y} \mathrm{H}$, et al. Complex microbial communities drive iron and 
sulfur cycling in Arctic fjord sediments. Appl Environ Microbiol. 2019;85:e00949-19.

113. Zhang H, Liu F, Zheng S, Chen L, Zhang X, Gong J. The differentiation of iron-reducing bacterial community and iron-reduction activity between riverine and marine sediments in the Yellow River estuary. Mar Life Sci Technol. 2020;2:87-96.

114. Ravenschlag K, Sahm K, Pernthaler J, Amann R. High bacterial diversity in permanently cold marine sediments. Appl Environ Microbiol. 1999;65:3982-9.

115. Kashefi K, Holmes DE, Baross JA, Lovley DR. Thermophily in the Geobacteraceae: Geothermobacter ehrlichii gen. nov., sp. nov., a novel thermophilic member of the Geobacteraceae from the "Bag City" hydrothermal vent. Appl Environ Microbiol. 2003;69:2985-93.

116. Holmes DE, Nicoll JS, Bond DR, Lovley DR. Potential role of a novel psychrotolerant member of the family Geobacteraceae, Geopsychrobacter electrodiphilus gen. nov., sp. nov., in electricity production by a marine sediment fuel cell. Appl Environ Microbiol. 2004;70:6023-30.

117. Jørgensen BB. Mineralization of organic matter in the sea bedthe role of sulphate reduction. Nature. 1982;296:643-5.

118. Bryant M, Campbell LL, Reddy C, Crabill M. Growth of Desulfovibrio in lactate or ethanol media low in sulfate in association with $\mathrm{H}_{2}$-utilizing methanogenic bacteria. Appl Environ Microbiol. 1977;33:1162-9.

119. Muyzer G, Stams AJ. The ecology and biotechnology of sulphate-reducing bacteria. Nat Rev Microbiol. 2008;6:441-54.

120. Dalsgaard T, Bak F. Nitrate reduction in a sulfate-reducing bacterium, Desulfovibrio desulfuricans, isolated from rice paddy soil: sulfide inhibition, kinetics, and regulation. Appl Environ Microbiol. 1994;60:291-7.
121. Holmes DE, Bond DR, Lovley DR. Electron transfer by Desulfobulbus propionicus to Fe (III) and graphite electrodes. Appl Environ Microbiol. 2004;70:1234-7.

122. Lovley DR, Phillips EJP. Competitive mechanisms for inhibition of sulfate reduction and methane production in the zone of ferric iron reduction in sediments. Appl Environ Microbiol. 1987;53: 2636-41.

123. Finke N, Vandieken V, Jørgensen BB. Acetate, lactate, propionate, and isobutyrate as electron donors for iron and sulfate reduction in Arctic marine sediments, Svalbard. FEMS Microbiol Ecol. 2007;59:10-22.

124. Canfield DE, Thamdrup B, Hansen JW. The anaerobic degradation of organic matter in Danish coastal sediments: iron reduction, manganese reduction, and sulfate reduction. Geochim Cosmochim Acta. 1993;57:3867-83.

125. Jørgensen BB. The sulfur cycle of a coastal marine sediment (Limfjorden, Denmark). Limnol Oceanogr. 1977;22:814-32.

126. Jørgensen BB, Laufer K, Michaud AB, Wehrmann LM. Biogeochemistry and microbiology of high Arctic marine sediment ecosystems - case study of Svalbard fjords. Limnol Oceanogr. 2021;66:S273-92.

127. Laufer K, Michaud AB, Røy H, Jørgensen BB. Reactivity of iron minerals in the seabed toward microbial reduction-a comparison of different extraction techniques. Geomicrobiol J. 2020;37:170-89.

128. Holmkvist L, Ferdelman TG, Jørgensen BB. A cryptic sulfur cycle driven by iron in the methane zone of marine sediment (Aarhus Bay, Denmark). Geochim Cosmochim Acta. 2011;75:3581-99.

129. Riedinger N, Brunner B, Formolo MJ, Solomon E, Kasten S, Strasser M, et al. Oxidative sulfur cycling in the deep biosphere of the Nankai Trough, Japan. Geology. 2010;38:851-4. 